\title{
Curative and Preventive Treatment for Cardiovascular Disease (CVD) Targeting Multiple Etiology
}

\author{
Josefino Ballesteros Tunac \\ Arterez, Inc., White Lake, Michigan, the United States
}

Email address:

drjoe@arterez.com

To cite this article:

Josefino Ballesteros Tunac. Tunac. Curative and Preventive Treatment for Cardiovascular Disease (CVD) Targeting Multiple Etiology. Cardiology and Cardiovascular Research. Vol. 5, No. 2, 2021, pp. 97-119. doi: 10.11648/j.ccr.20210502.18

Received: May 19, 2021; Accepted: May 31, 2021; Published: June 15, 2021

\begin{abstract}
Gene deficient or knockout (KO) mice and rabbits are models of atherosclerosis focusing on cholesterol plaques, which do not reflect the complex etiology of cardiovascular disease (CVD). Inhibiting the 3-hydroxy-3-methyl-glutarylcoenzyme A (HMG-CoA) reductase or the proprotein convertase subtilisin/kexin type 9 (PCSK9) reduce cholesterol levels but not the rate of CVD. Moreover, the one-drug-one-gene paradigm particularly targeting any one of the $\mathrm{G}$ protein-coupled receptors (GPCRs), which represent the largest protein family encoded by the human genome, has at best produced palliative treatment. Vascular diseases including CVD are caused by extraneous (xeno) factors, which are of multifactorial etiology consisting of upstream and downstream phases. The upstream phase is the physical breach of the cells protective glycocalyx (GCX) shield by chemical and biological pollutants, resulting in a sequela of cell damages (plexic) that is manifested downstream in the form of diseases, herein called xenoplexic diseases. Xenoplexic disease is an etiologic description while chronic disease is symptom-centric. This study treated a natural mouse with extraneous agents, which produced plaques and plaque reduction was the end point to evaluate the curative and/or preventive treatment effect of the 3-component compound therapy. Histopathology monitored the presence of plaque, and a 4-panel biomarker, based on GCX disruption, was subsequently developed as a surrogate to monitor plaque formation. Of the several 3-NCE combos tested 4 combos were found to be preventive and curative of plaques indicating the effectiveness of a combo platform therapy. One combo is chosen as the lead candidate and hereby designated as Embotricin ${ }^{\mathrm{TM}}$.
\end{abstract}

Keywords: Cardiovascular Disease (CVD), Glycocalyx (GCX), Xenoplexic Disease, Combo Therapy

\section{Introduction}

\subsection{Incidence of Cardiovascular Disease (CVD)}

Cardiovascular disease (CVD) refers to a group of disorders that includes hypertension, coronary artery disease, peripheral artery disease, stroke, congenital heart disease, and heart failure [1]. CVD is the leading cause of death and disability, killing 655,000/year in the US (CDC) and 17.9 million people/year in the world (WHO), which accounts for a third of all deaths and half of all non-communicabledisease-related deaths. The available drugs vs CVD are palliative at best because they are symptom targeted. There is no curative drug against this disease because the pervading one-drug-one disease paradigm is symptom-centric, which develop one drug to target a symptom. For example, diuretics, angiotensin converting enzyme (ACE) inhibitors, angiotensin receptor blockers (ARBs), calcium antagonists, and beta blockers to treat symptoms of hypertension; statins or 3-hydroxy-3-methyl-glutaryl-coenzyme A (HMG-CoA) reductase, inhibitors of the proprotein convertase subtilisin/kexin type 9 (PCSK9), bile-sequestrants, fibrates, niacin to treat lipidemia/hypercholesterolemia; and antiplatelets, anticoagulants, fibrinolytics for blood pooling.

\subsection{Trends in Drug Development}

\subsubsection{Pharmacognosy and Early Medicines}

Pharmacognosy is the exploitation of secondary metabolites found in natural products, including plants, animals, and microorganisms as sources of pharmaceuticals [2]. The effectiveness of plant extracts (folk medicine) as early medicines was due the synergistic effect of complex mixtures of molecules.

However, in the second half of the 20th century, progress 
in science allowed the purification and isolation of active ingredients. For example, the isolation of morphine (1804), quinine and colchicine (1820), atropine (1833), and cocaine (1860), shifted drug research into the "one drug-one targetdisease" philosophy [3] assuming that these were the 'onecomponent' responsible for activities. This paradigm prompted the mass screening of microbial metabolites in the '40s searching and isolating that 'one-component', which paid dividends marking the golden era of antibiotics [4]. Microbial metabolites were subsequently exploited for chemotherapeutic agents [5], which yielded number of anticancer agents [6].

\subsubsection{Genomic Drug Target}

The 'one drug-one target' complements the 'one gene-one enzyme' concept of Tatum and Beadle in the early 1940s [7]. The premise is to identify a specific enzyme associated in the disease ontology and inhibits its activity. For example, screening of 3-hydroxy-3-methylglutaryl coenzyme A (HMG-CoA) reductase (key enzyme in cholesterol biosynthesis) yielded the parental statin compactin [8]. Subsequently, the Human Genome project promised some 30,000 genes as "druggable" targets [9].

However, finding the target gene for a 'magic-bullet' has proven to be unsuccessful [10], because $>90 \%$ of disease risks are due to lifestyle and environments [11]. For example, genetic factors only make a minor contribution to chronic diseases [12] while the majority accounted for by environment [13].

\subsubsection{Epigenetic and Chronic Diseases}

Environmental exposures and lifestyle modulate gene expression through epigenetic processes [14]. Genes, studied under genetics, are basic units of heredity described by a specific nucleotide pattern; the changes in gene activity during development are studied under epigenetics [15]. Epigenetic changes can be a cellular (stem cell) or a molecular (cell division) phenomenon [16]. The predominant epigenetic mark is methylation at cytosine in 5'-cytosinephosphodiester bond-guanine-3' (CpG) dinucleotides to produce 5-methylcytosine $(5 \mathrm{mC})$ [17] during oxidative stress [18], which is temporally stable for weeks and elicit distinct biological responses [19] or passed through cell division with the help of DNA methyltransferases (DNMTs) as heritable epigenetic change. In CVD, epigenetic changes start with endothelial disruption [20].

\subsubsection{Polypharmacology and Diseases}

The 'one drug-one target' platform assumes that a drug with a specific target does not have off-target side-effects. However, a single drug could be promiscuous, interacting with 6-28 targets [21]. In this regard, polypharmacology was conceived almost 25 years ago to exploit the promiscuity of a single drug [22] acting on multiple targets of a disease pathway, or single drug acting on multiple targets pertaining to multiple disease pathways [23]. Sunitinib exemplifies polypharmacological drug targeting, which activates the multiple receptor tyrosine kinases (RTKs) becoming the first drug to be approved for two separate indications simultaneously, including gastrointestinal and kidney cancers [24].

An extension of polypharmacology is 'systems pharmacology' (or 'systems therapeutics'), aimed at targeting biological networks rather than single transduction pathways [25] and the products are referred to as multi-target or systems pharmacology drugs [26].

\subsubsection{Precision Medicine}

An evolution of polypharmacology is precision medicine [27]. The term 'precision medicine' was first coined in 2009 [28], which tailors medical treatment with medical decisions, treatments, practices, or products to a subgroup of patients, instead of a one-drug-fits-all model [29]. Thus, diagnostic testing is employed to customize appropriate and optimal therapies based on a patient's genetic content or other molecular or cellular analysis [30], which includes molecular, imaging, and analytics [31].

\subsubsection{Combination Drug Treatment}

In the golden era of antibiotics, these drugs were initially prescribed as monotherapies and then expanded to fixed-dose combinations (FDC). FDC was championed by the head of the FDA's Division of Antibiotics, Henry Welch, who endorsed Sigmamycin (tetracycline and oleandomycin: Pfizer) and Panalba (tetracycline/novobiocin: Upjohn) [32]. While Sigmamycin components demonstrated clear synergic action [33], Panalba's two active agents mutually inhibited each other and decreased efficacy [34], which prompted an FDA review and eventual recall of this FDC in late 1959.

The efficacy requirement for FDA drug approval was eventually embedded in the Kefauver-Harris Amendments of 1962 before approval of FDCs [35]. Compliant with the efficacy amendment, Bactrim (sulfamethoxazole and trimethoprim) was approved by the FDA in 1973 as the first antibiotic FDC and has become a drug mainstay in the treatment of ear infections, bronchitis, pneumonia, urinary tract infections (UTIs), intestinal infections, traveler's diarrhea [36]. Bactrim components work synergistically through consecutive steps in bacterial folate metabolism halting the growth of bacteria [37].

Effect of combined drugs could be antagonistic, additive, or synergistic [38]. Currently, the increased number of monotherapy drugs that lack efficacy is the driver for combination drugs to search for synergy. Synergistic drug combinations have numerous advantages over monotherapy, including increased efficacy, decreased dosage with equal efficacy, reduced side effects and reduced drug resistance [39].

\subsection{The Molecular Roots of CVD}

\subsubsection{Dysfunctional Blood Flow}

The cardiovascular system starts with the heart, which pumps oxygenated blood through branching arteries, arterioles, and capillaries to tissues. Deoxygenated blood is returned through the veins per muscle contraction squeezing blood back to the lung for re-oxygenation. A balanced blood pressure and osmotic pressure create a healthy blood flow, 
which is aided by a slippery lining at the surface of the vessel called glycocalyx (GCX). GCX is a negatively charged, $\sim 0.5-5 \mu \mathrm{m}$, layer lining the microvasculature, which allows negatively charged red blood cells (RBC) to glide through the narrow capillary beds [40]. GCX disruption due to environmental factors result in dysfunctional blood flow and a sequela of CVD [41].

The outer ornamentation of GCX are sulfated glycosaminoglycosides (GAG), notably heparan sulfate (HS). HS confers negative charge for GCX as well as the red blood cells (RBC) and negative charges repel, which allows a frictionless flow of RBC through the GCX lining [42]. However, when the GCX surface of either unit is breached, $\mathrm{Na}^{+}$ions are exposed (normally buried in the GCX bed), creating 'positive patches' and disrupts blood flow causing hypertension (HTN) [43]. Moreover, disruption of the GCX exposes other electrolytes embedded on either side of the membrane triggering a family of CVD diseases [44].

\subsubsection{Disruption of Glycocalyx (GCX) Affects Blood Flow}

All cells in the human body are covered by GCX, including the endothelium of arteries called the arterial endothelial glycocalyx (AEG). AEG is multifunctional, serving as a protective lining, a nest to blood-flow regulating components [45], filters off cell debris, acts as a sensor to changes in the microenvironment and then regulates vascular tone, level of circulating cell adhesion molecules, coagulation, fibrinolysis, and inflammation of the vessel wall [46]. Disruption or dysfunction of AEG is a first step in the atherosclerosis process, which is reflected by shedding of components (detritus) including proteoglycans and glycoproteins [47]. The glycoproteins are protein-glycan conjugates that make up three families of adhesive molecules, which include the selectin family, the integrin family, and immunoglobulin superfamily that act as a mechanotransductor of shear stress [48]. Damage to the glycocalyx precedes vascular pathology [49].

\subsubsection{Food and Environmental Pollutants Produce Oxidants}

Food is metabolized to extract electrons from hydrogen and shuttled through the electron transport system (ETS) by the electronegative oxygen to generate energy. However, $\sim 2 \%$ electrons leak from the ETS and reacts with molecular oxygen [50]. Sequential reduction of the two unpaired electrons of molecular oxygen leads to formation of a family of reactive oxygen species (ROS), which in excess are oxidative. Optimum ROS levels are beneficial, which is maintained by built-in antioxidant enzymes [51]. However, overeating [52], high fat diet [53] and exposure to stressful environment produce extraneous ROS, which favors an oxidative balance [54-56]. Chronic exposure to environmental chemicals, including persistent organic pollutants, volatile and semi-volatile organic compounds, radiation, pathogens, allergens, and psychological stress, generates extraneous ROS leading to GCX disruption [57] (Figure 1).

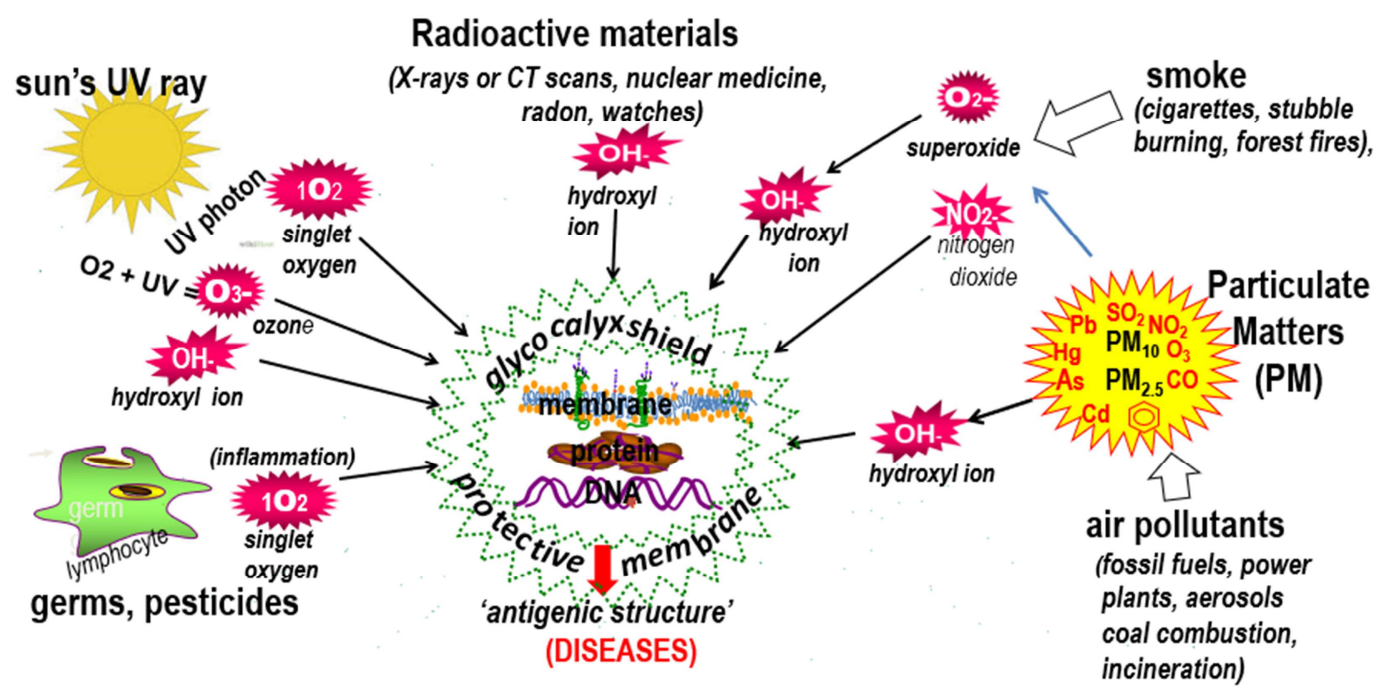

Figure 1. Environmental factors generate reactive oxygen species (ROS) and disrupt the cells protective glycocalyx (GCX).

Oxidative damage to GCX [58] generates debris or detritus, which become antigenic resulting in inflammation and additional ROS. The antigenic molecules triggers inflammation by the release of histamine, an organic nitrogenous compound stored in mast cells and basophils, which binds to various cellular receptors. Histamine increases the permeability of the capillaries to white blood cells and some proteins, to engage with the antigens (pathogens, xenobiotics) [59]. In distressed tissues, histamine regulates the fate of the cell [60] and failure to recover from distress result is cell death (i.e., apoptosis, necrosis, pyroptosis, or autophagic cell death) [61]. In this regard, modulation of histamine is a therapeutic strategy for the prevention or treatment of CVD [62].

\subsubsection{High Fat Diet Creates Viscous Blood}

Fats or triglycerides (TAG) are the best source of energy (9 calories/gram) but not soluble in water, hence they are packaged in lipoprotein for delivery to tissues. Very low- 
density lipoprotein (VLDL) packages TAG along with liverproduced cholesterol and once the fat cargo is unloaded, VLDL becomes low-density lipoprotein (LDL), which is the desired lipoprotein that delivers cholesterol to tissues via the LDL-receptor (LDL-R) [63]. If the LDL-R is compromised, either by AEG disruption or genetic, LDL cannot be delivered to tissues and consequently a buildup of LDL. For example, Brown and Goldstein discovered a genetically defective LDL-R causing familial hypercholesterolemia $(\mathrm{FH})$ [64]. Because of this discovery, LDL, has since been labeled 'bad cholesterol'. Essentially all LDL particles are derived from VLDL and all VLDL goes to LDL [65]. On the other hand, high density lipoprotein (HDL) is mainly secreted by the liver (70-80\%) and small intestines. HDL exchanges TAG via cholesteryl ester transfer protein (CETP) or plasma lipid transfer protein (PLTP) with VLDL and LDL [66], giving HDL the moniker as "good cholesterol".

A high TAG diet means high VLDL, resulting in viscous blood and risk of CVD death [67]. VLDL is the most atherogenic triglyceride remnant lipoprotein (TGRL) [68], which rapidly penetrates the arterial wall, increases endothelial inflammation, and facilitates the infiltration of monocytes forming foam cells resulting in atherosclerosis [69]. A diet of saturated fatty acid is associated with a high CHD risk [70]; even just one fat meal load in healthy young men reduces coronary blood flow [71].

On the other hand, low TAG diet reduces incidence of CVD [72], which is consistent with the Mediterranean diet [73]. Every animal-based food contains both cholesterol and fats with a constant cholesterol content (except egg yolk and cheeses) while the fat content varies, with beef averaging $9.6 \%$ fat [74]; the Western diet averages $21 \%$ fat and $0.15 \%$ cholesterol. Cholesterol in the diet does not cause atherosclerosis because liver-produced cholesterol 7 $\alpha$ hydroxylase (CYP7A1) converts it into bile [75]. Most of the cholesterol supply in the body are synthesized de novo, which is tightly regulated to prevent over- accumulation and abnormal deposition within the body [76]. For these reasons, cholesterol intake in food has little, if any, effect on total body cholesterol content or concentrations of cholesterol in the blood [77].

\subsubsection{Viscous Blood Creates Whirlpool Pockets and Low Shear Stress}

The straight arterial segment allows unimpeded blood flow typical of high endothelial shear stress (ESS) and a thick protective GCX layer. On the other hand, segments of bends or bifurcations with oscillating blood flow have low ESS [78], typically thinner GCX lining and prone to endothelial injury and atherosclerosis [79]. Such bends are found in the aortic arch, carotid sinus, brain, heart, and limbs [80]. On the other hand, the descending thoracic aorta, where blood flow is uniform and unidirectional with high ESS, does not form plaque [81]. Normal and high ESS are atheroprotective being involved in compensatory remodeling, but when remodeling fails, the plaque intrudes into the lumen [82].

Low ESS are generated in whirlpool pockets, which traps environmental pollutants and debris including dead cells, 'microbial contaminants and particulate matters (PMs) e.g., chemicals, smoke, pollutants, particulate matters. PMs, particularly $\mathrm{PM}_{2.5}$ trigger oxidative stress, inflammation and endothelial dysfunction [77]. These, factors combine to further compromise a fragile GCX at such sites, exposing the endothelium to injury creating 'tiny gaps', subsequently blood debris and macrophage infiltration to form plaque (Figure 2).

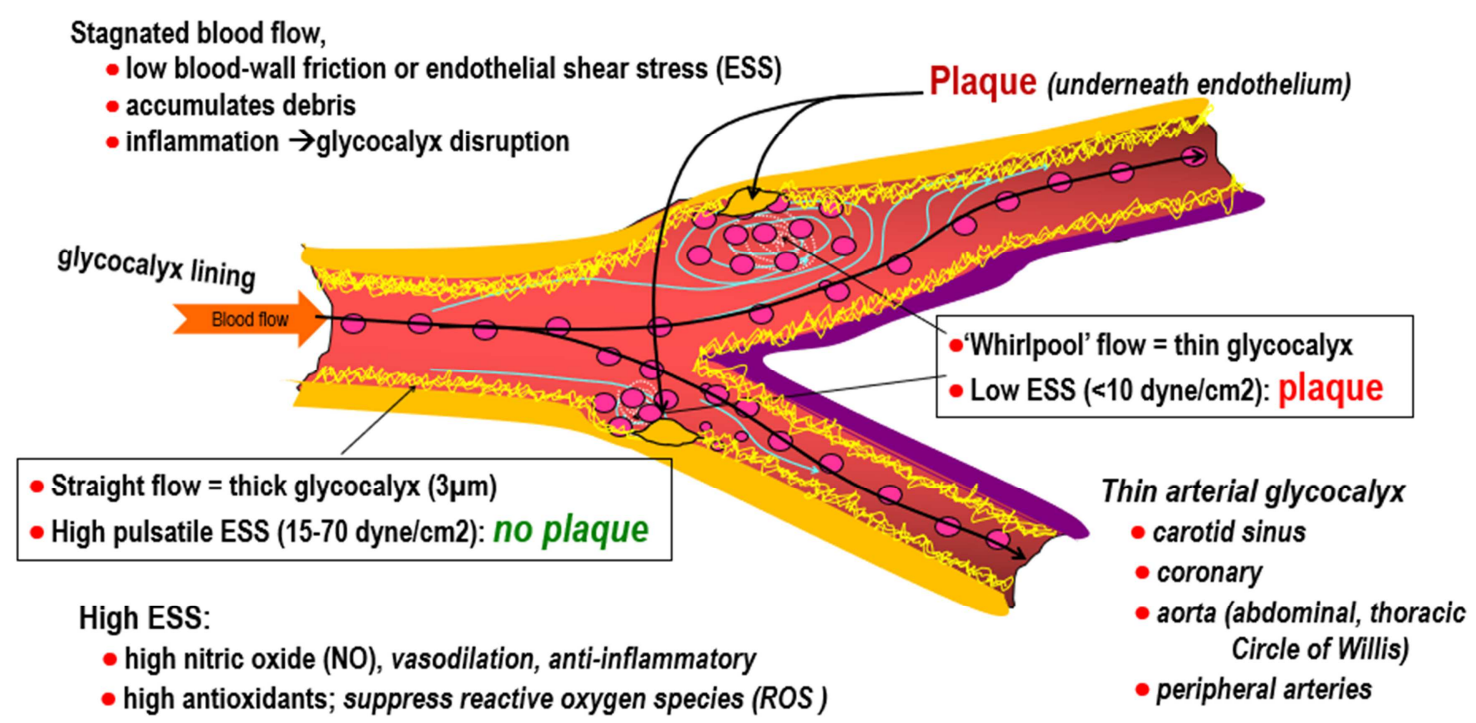

Figure 2. Blood flow slows down at arterial forks and bends, creating a "whirlpool pocket" and plaque sites.

\subsubsection{Coronary Arteries Have Most Bends and Plaques}

The carotid sinus and coronary arteries are plaque prone because they have the most bends and bifurcations. Of the coronary arteries, the left anterior descending (LAD) has at least 4 bends and as many plaques accounting for coronary heart disease (CHD) as the most prominent of CVD cases [83]. Acute infection or injury [84]. ruptures vulnerable plaques, which triggers thromboembolism [85]. Thrombosis 
and embolism are similar but occur in unique conditions: thrombosis occurs when a thrombus, or blood clot, develops in a blood vessel and reduces the flow, while embolism occurs when a piece of a blood clot, foreign object, or other bodily substance becomes stuck in a blood vessel and obstructs blood flow. Thromboembolism is the obstruction of vessel beds by embolic material derived from a thrombus from a distant site which could be arterial thromboembolism
(ATE) or venous thromboembolism (VTE) that includes deep-vein thrombosis (DVT) [86]. Thrombus formation on a fissured or ruptured plaque is the main pathogenetic mechanism for unstable angina and the acute coronary syndromes including stroke, heart attack and peripheral arterial disease (PAD) [84, 87-90] with CHD accounting for $47.7 \%$ death (Figure 3 ).

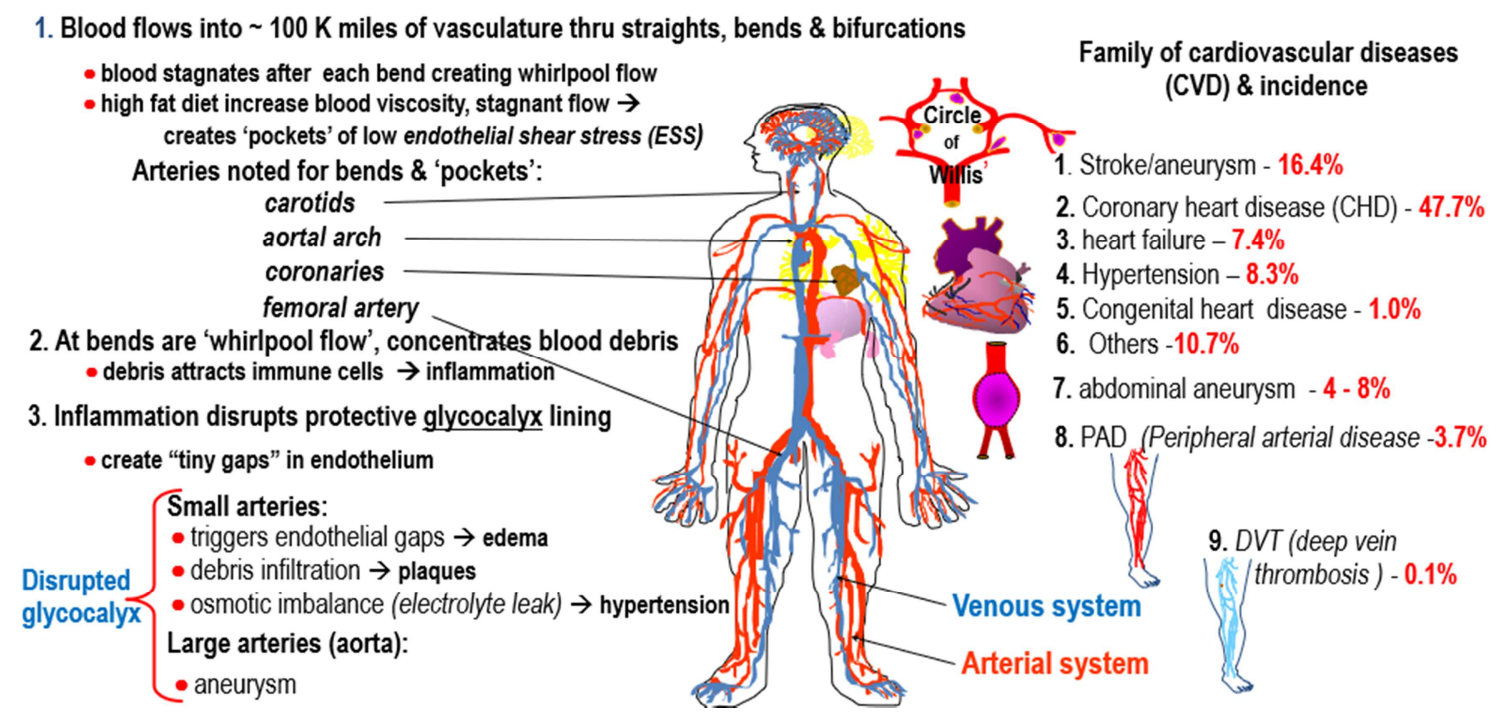

Figure 3. Family of CVD as manifested in different parts of the vascular system.

\subsection{Animal Models for Drug Discovery}

\subsubsection{Rabbit as Early Model for Atherosclerosis}

Associating elevated level of blood cholesterol to CVD was borne out of an experiment by a Russian scientist (Ignatowski) who fed meat, eggs and milk to a rabbit and observed arterial lesions (aka, "fatty streaks", "cholesterol plaque"), which begat the "Cholesterol Hypothesis" [91] Rabbits, being herbivore, do not have the innate ability to metabolize meat products including fat and cholesterol, consequently they accumulate in the circulation and deposited as arterial lesions. This serendipitous experiment was misconstrued to happen also in humans, which established the consensus that dietary cholesterol leads to the development of atherosclerosis in both animals and humans. This is a flawed hypothesis because humans are naturally equipped with an enzyme, cholesterol hydroxylase (CYP7A1), that converts cholesterol to bile and prevent cholesterol accumulation. Indeed, arterial lesions in cholesterol-fed rabbits regressed when switched to low-fat chow $[92,93]$. Regardless, the rabbit became a de facto model in the study of the pathogenesis and development of human atherosclerosis. The rising incidence of heart disease in the $20 \mathrm{~s}$ evoked the Russian "Cholesterol Hypothesis" and became the foundation of the "War on Cholesterol" to treat CVD [94]. In 1986 the National Institutes of Health (NIH) and the American Heart Association (AHA) established the National Cholesterol Education Program (NCEP) to officially declare blood cholesterol over $200 \mathrm{mg} / \mathrm{dl}$ as a disease, which cause atherosclerosis in humans. On the other hand, carnivores like dog only develop atherosclerosis via a defective thyroid gland [95]. Dogs with hypothyroidism have increased very lowdensity lipoproteins (VLDL), LDL, and HDL [96]. A cat, another carnivore, becomes obese on carbohydrate diet [97]. because carbohydrate is not essential for cats [98].

\subsubsection{Gene deficient Animals as Models for Atherosclerosis}

The discovery of the LDL-R gene inspired the development of gene deletion or knock-out (KO) mice and became a default model for cholesterol buildup, which was instrumental in the discovery of the cholesterol-lowering statins. KO models include the LDL-R (LdlR-/-) mouse [99], and the apolipoprotein E (ApoE-/-) mouse [100, 101]. Currently, the ApoE-/- mouse is the model of choice in the study of human atherosclerosis and accounted for the development of more statins and PCSK9 inhibitors including Repatha and Praluent.

\subsubsection{KO Mouse or Rabbit Plaques Are Not the Same as Humans}

Although KO mice and rabbits have conceptually modeled plaque formation, none of them exhibit the full characteristics seen in humans. $\mathrm{KO}$ mice do not reflect the human form of atherosclerosis [102] and thrombosis [103]. KO mice "plaques" are superficial cholesterol lesions with no fibrous cap [104-106], while human plaques are subendothelial with thick fibrous cap of collagen and elastin [107] (Figure 4). The fibrous cap made up of intimal smooth muscle cells and connective tissue is a healing response to encapsulate the toxic products accumulating in the necrotic 
core of atherosclerotic lesions [108].

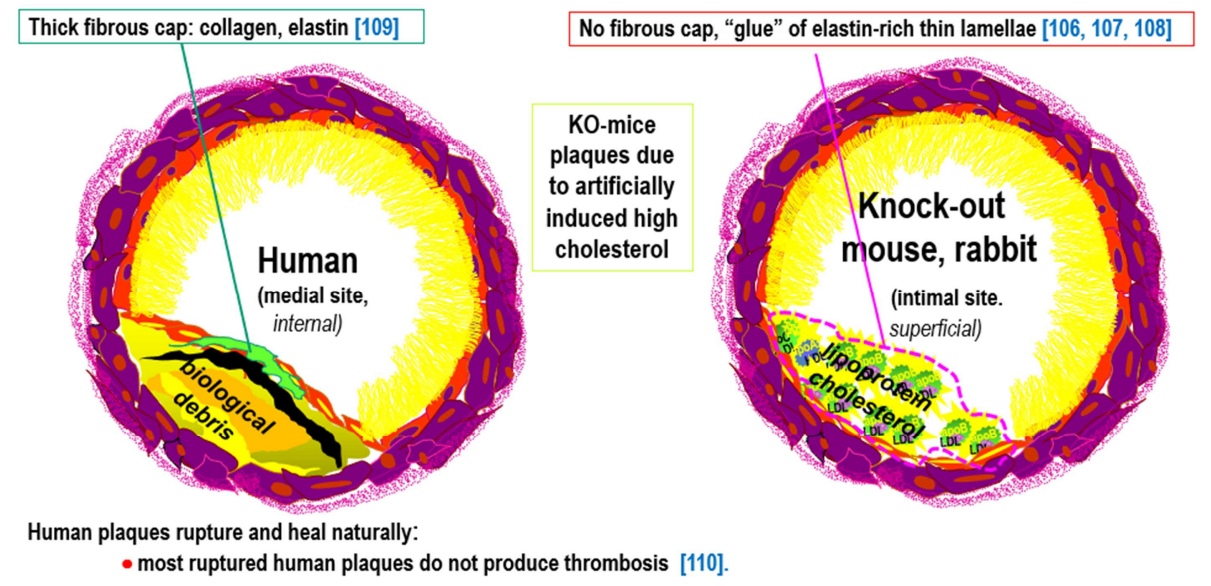

Figure 4. Plaques produced in animal models are superficial, while human plaques are subendothelial.

\subsubsection{Classification of Atherosclerotic Plaques}

Traditionally, two types of clinical plaques are described based on rabbit model: fatty streak (a thin lipid deposit in thin intima in children) and fibrous plaque (a thick fibrolipidic lesion in adults). Fatty streaks in infants were described as yellow dots, visible to the unaided eye at the root of the aorta, which become more extensive at puberty and in adults, then develop to complex fibrolipid or fibrous plaque [109]. The World Health Organization [110] classified plaques as atheroma (predominantly lipid component) and fibrous (predominantly collagenous component). Other terms include fibroatheroma, atheromatous plaque, fibrolipid plaque, or fibrofatty plaque to mean atherosclerosis [111].

AHA initially classified plaques into 3 types; the assumption was for type I to progress through type III [112]. However, the transition from type II to type III was not well defined, and thus the use of ApoE-/- knock-out mouse to model plaque transition and classification (Table 1).

Table 1. Three types of plaques to unify lesions from cholesterol-fed animals with clinical data.

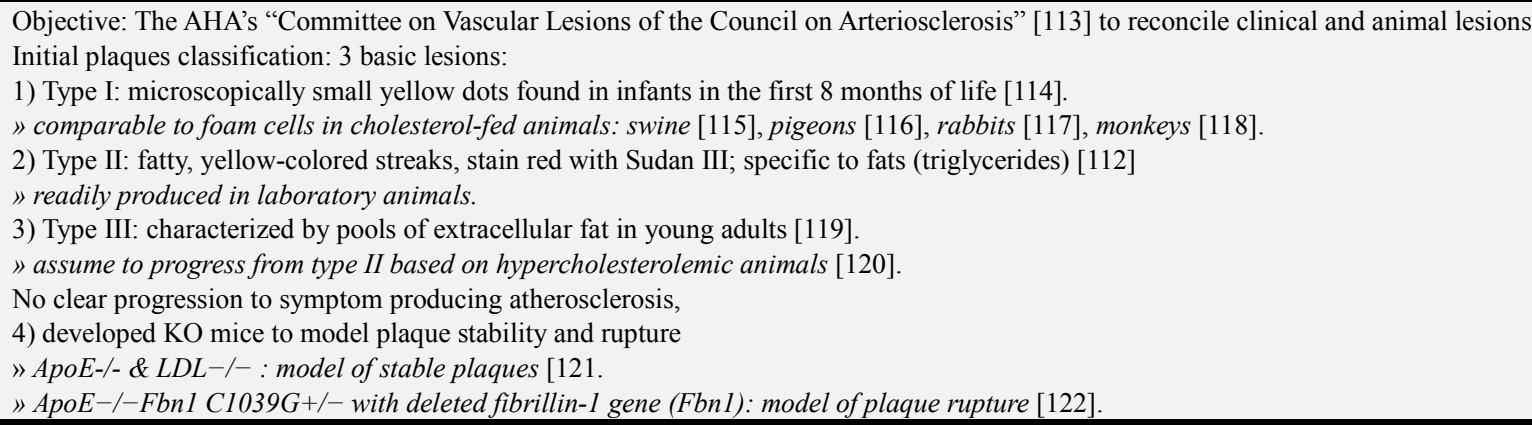

\subsection{Biomarkers of CVD}

Biomarker is a biological element measured and evaluated as an indicator of normal biological- or pathogenic-processes and pharmacologic responses to a therapeutic intervention [123]. Consistent with the one-drug-one-disease paradigm, a single biomarker is selected a priori to diagnose a disease. The appeal of a single marker is its simplicity and low cost, but does not capture the xenoplexic nature of CVD, which makes a single biomarker non-specific, inaccurate, and nonsensitive.

In the clinic, diagnosis of diseases is typically surmised from symptoms, patient history, physical examination and often, one or more medical tests. However, many signs or symptoms are nonspecific. For example, cardiovascular disease, diabetes, or cancer displays multiple symptoms and therefore each of these diseases needs differential diagnosis to improve accuracy. An ideal biomarker should be diagnostic (disease presence), prognostic (measure outcome) and predictive. The rapid and correct identification of diseases is crucial and important as a guide for appropriate therapy.

Consistent with the xenoplexic nature of CVD, numerous biomarkers have been identified to be associated with this disease [124], but no single biomarker is yet found to be reliable in predicting or diagnosing a cardiovascular event, thus a trend towards a panel [125]. In this study, 4 biomarkers were identified from GCX shedding, including heparan sulfate (HS), hyaluronan synthase-1 (HAS-1), syndecan-1 (SDC-1) and plasminogen activator inhibitor-1 (PAI-1) [126]. Each of these molecules have been used in the clinic as single biomarkers (Table 2) but will be used in this study as a 4-panel diagnostic "fingerprint" to monitor therapeutic efficacy. 
Table 2. Biomarker levels in blood of diseased and healthy patients.

\begin{tabular}{|c|c|c|c|c|}
\hline \multirow{2}{*}{ Biomarker } & \multirow{2}{*}{ Disease type } & \multicolumn{2}{|l|}{ Level } & \multirow{2}{*}{ References } \\
\hline & & Healthy & Diseased & \\
\hline \multicolumn{5}{|c|}{ Syndecan-1 (SDC1) } \\
\hline & Myeloma & 128 units $/ \mathrm{mL}$. & 1170 units/mL & [127]. \\
\hline & Lung cancer (SCLC) & $16 \mathrm{ng} / \mathrm{ml}$ & $44 \mathrm{ng} / \mathrm{ml}$ & [128] \\
\hline & Heart failure & $1.19 \mathrm{ng} / \mathrm{ml}$ & $4.14 \mathrm{ng} / \mathrm{ml}$ & [129] \\
\hline & Inflammatory bowel disease (IBD) & $21.2 \mathrm{ng} / \mathrm{mL}$ & $29.5 \mathrm{ng} / \mathrm{mL}$ & {$[130]$} \\
\hline & Acute decompensated HF (ADHF) & $91.4 \mathrm{ng} / \mathrm{ml}$ & $133.7 \mathrm{ng} / \mathrm{ml}$. & {$[131]$} \\
\hline & Chronic heart failure & $5.7 \mathrm{ng} / \mathrm{mL}$ & $22.5 \mathrm{ng} / \mathrm{mL}$ & [132] \\
\hline & Acute coronary syndrome (ACS) & $42 \mathrm{ng} / \mathrm{ml}$ & $77 \mathrm{ng} / \mathrm{ml}$ & {$[133]$} \\
\hline & Global and regional ischemia & $1.2 \mathrm{ug} / \mathrm{dL}$ & $50.41 .2 \mathrm{ug} / \mathrm{dL}$ & [134] \\
\hline & Preeclampsia & $28 \mathrm{ng} / \mathrm{mL}$ & $218 \mathrm{ng} / \mathrm{mL}$ & {$[135]$} \\
\hline & Renal failure & $27.5 \mathrm{ng} / \mathrm{ml}$ & $111.0 \mathrm{ng} / \mathrm{ml}$ & [136] \\
\hline & Ischemia & $1.2 \mu \mathrm{g} / \mathrm{dL}$ & $1.38 \mathrm{ug} / \mathrm{dL}$ & [137] \\
\hline & Hemorrhagic Shock & $27 \mathrm{ng} / \mathrm{ml})$. & $554 \mathrm{ng} / \mathrm{ml}$ & {$[138]$} \\
\hline \multicolumn{5}{|c|}{ Heparan sulfate (HS) } \\
\hline & Dengue fever (hemorrhagic & $16.78 \mathrm{ng} / \mathrm{ml}$ & $108.55 \mathrm{ng} / \mathrm{ml}$ & [139] \\
\hline & Ischemia & $590 \mathrm{ug} / \mathrm{dL}$ & $5,900 \mathrm{ug} / \mathrm{dL}$ & {$[140]$} \\
\hline & Mucopolysaccharidoses (MPS) & $12.4 \mathrm{ug} / \mathrm{ml}$ & $24.4 \mathrm{ug} / \mathrm{ml}$ & {$[141]$} \\
\hline & Hypertension (pre-eclampsia) & $60.5 \mathrm{mg} / \mathrm{l}$ & $123.1 \mathrm{mg} / 1$ & {$[142]$} \\
\hline \multicolumn{5}{|c|}{ Hyaluronan synthase (HAS-1) } \\
\hline & Arthritis & $29.1 \mathrm{ng} / \mathrm{ml}$ & $37.4 \mathrm{ng} / \mathrm{ml}$ & {$[143]$} \\
\hline & Stroke & $170.4 \mathrm{ng} / \mathrm{ml}$ & $219.7 \mathrm{ng} / \mathrm{ml}$ & [139] \\
\hline & Liver disease (alcoholic cirrhosis) & $0.03 \mathrm{ng} / \mathrm{ml}$ & $1.08 \mathrm{ng} / \mathrm{ml}$ & {$[144]$} \\
\hline & liver cirrhosis & $30-40 \mathrm{ug} / \mathrm{L}$. & $100-300 \mathrm{ug} / \mathrm{L}$ & {$[145]$} \\
\hline & Hepatitis (chronic) & $117.86 \mathrm{ng} / \mathrm{ml}$ & $575.93 \mathrm{ng} / \mathrm{ml}$ & {$[146]$} \\
\hline & Fibrosis & $16 \mu \mathrm{g} / \mathrm{l}$ & $121 \mu \mathrm{g} / 1$ & {$[147]$} \\
\hline & malignant pleural mesothelioma & $\leq 49 \mu \mathrm{g} / \mathrm{ml}$ & $>100 \mu \mathrm{g} / \mathrm{ml}$ & {$[148]$} \\
\hline & Septicemia & $11 \mathrm{ug} / \mathrm{L}$ & 344 ug/L: & [149] \\
\hline & acute stroke patients & $170.4 \mathrm{ng} / \mathrm{ml}$ & $219.7 \mathrm{ng} / \mathrm{ml}$ & [139] \\
\hline & Dengue fever & $100.11 \mathrm{ng} / \mathrm{ml}$ & $935.91 \mathrm{ng} / \mathrm{ml}$ & {$[150]$} \\
\hline \multicolumn{5}{|c|}{ Plasminogen activator inhibitor 1 (PAI-1) } \\
\hline & ischemic sroke: & $11.8 \mathrm{IU}$. & $17.2 \mathrm{IU}$ & {$[151]$} \\
\hline & Acute Stroke & $23.6 \mathrm{ng} / \mathrm{ml}$ & $45.2 \mathrm{ng} / \mathrm{ml}$ & {$[152]$.} \\
\hline & Chronic angina pectoris & $9.6 \mathrm{U} / \mathrm{ml})$ & $17.5 \mathrm{U} / \mathrm{ml})$ & {$[153]$} \\
\hline & Acute myocardial infarction & $10.1 \mathrm{ng} / \mathrm{ml}$ & $16.3 \mathrm{ng} / \mathrm{ml}$ & {$[154]$} \\
\hline & Angina & $40.0 \mathrm{ng} / \mathrm{mL}$ & $95.4 \mathrm{ng} / \mathrm{mL}$ & {$[155]$} \\
\hline & Coronary arterial disease (CAD) & $2.97 \mathrm{ng} / \mathrm{ml}$ & $5.26 \mathrm{ng} / \mathrm{ml}$ & {$[156]$} \\
\hline & Acute myocardial infarction & $9.35 \mathrm{ng} / \mathrm{ml}$ & $44.02 \mathrm{ng} / \mathrm{ml}$ & {$[157]$} \\
\hline & Hypertension: & $32.1 \mathrm{ng} / \mathrm{mL}$ & $39.8 \mathrm{ng} / \mathrm{mL}$ & {$[158]$} \\
\hline & Coronary Artery Disease & $2.4 \mathrm{ng} / \mathrm{ml}$ & $8.8 \mathrm{ng} / \mathrm{ml}$ & {$[159]$} \\
\hline & ST-elev myocardial infarction (STEMI) & $16.1 \mathrm{U} / \mathrm{mL}$ & $21.9 \mathrm{U} / \mathrm{mL}$ & {$[160]$} \\
\hline & Glioma & $2.5 \mathrm{ng} / \mathrm{ml}$ & $14.7 \mathrm{ng} / \mathrm{ml}$ & {$[161]$} \\
\hline & Acute Myocardial Infarction & $10.0 \mathrm{ug} / \mathrm{L}$ & $15.1 \mu \mathrm{g} / \mathrm{L}$ & {$[162]$} \\
\hline
\end{tabular}

Indeed, monitoring GCX shedding promises to be an important diagnostic tool for CVD in clinical settings [163]. However, the current GCX diagnostic techniques involve direct and indirect microscopy [164], which are impractical.

\section{Objectives}

KO mice and rabbits are models of atherosclerosis focusing on cholesterol plaques, and do not reflect the multiple nature of cardiovascular disease (CVD). One-drugone-target paradigm has produced the statins but are at best palliative. CVD is a xenoplexic disease and this study aims to address its complex etiology by combo-compound therapy.

Evaluation of therapeutic effect will use a wild mouse made atherosclerotic by xenobiotics including high fat diet and an environmental pollutant [125]. The objectives of this study are:
1. Construct a virtual etiology of CVD, particularly a thromboembolic cascade, and identify "druggable" targets.

2. Synthesize new chemical entities (NCEs) to target specific sites in the thromboembolic cascade.

3. test these NCEs in combo to address in toto the xenoplexic nature of the disease.

4. Confirm plaque formation with histopathology and create a 4-panel biomarker as a surrogate diagnostic 'fingerprint'.

5. Evaluate drug effectiveness in both preventive and curative mode.

\section{Materials and Methods}

\subsection{Mice}

A wild type C57BL/6 mouse, non-genetically altered 
mouse is used as an atherosclerosis model [125] for this study. Briefly, arterial plaque formation was achieved by treating wild $\mathrm{c} 57 \mathrm{Bl} / 6$ with high fat and $\mathrm{PCB}$, which produced plaques as confirmed by histopathology. This mouse model was used in this study and herein called the Tunac Arterial Plaque (TAP) mouse model. Thus, eighty-four (84) ten-weekold male C57/B16 mice were obtained from Jackson Laboratories. Three mice were raised from 6 weeks on a regular diet (5001 LabDiet Rodent 5001) and served as controls, and the remaining mice were raised on a $60 \%$ fat diet (D12451, DIO series diet, Opensource Diets). Ethics regulation of laboratory animals: This study was conducted in accordance with the Guide for the Care and Use of Laboratory Animals published by the US National Institutes of Health (NIH Publication No. 85-23, revised 1996).

\subsection{Treatments}

It is well known that environmental pollutants including the lipophilic persistent organic pollutants (POPs), such as polychlorobiphenyls (PCBs), accumulate in fatty tissues [165]. PCB was chosen for this study because they are the most ubiquitous environmental pollutant. $\mathrm{PCBs}$ are resistant to acids and bases as well as to heat and have been used as an insulating material in electric equipment, such as transformers and capacitors, and in heat transfer fluids and in lubricants, as plasticizers, surface coatings, inks, adhesives, flame-retardants, paints, and carbonless duplicating paper. Pollutants disrupt certain signaling and differentiation pathways and induce inflammation in the adipose tissues [166]. For this study 3, 3', 4, 4'-Tetrachlorobiphenyl (PCB77) was obtained from Neosyn Laboratories. The dry chemical was suspended in $15.22 \mathrm{ml}$ of corn oil to deliver $200 \mu \mathrm{mol} / \mathrm{kg}$ in $0.2 \mathrm{ml}$ by gavage per mouse according to the treatment schedule.

Compounds tested for therapeutic activities were suspended in $8 \mathrm{ml}$ carboxymethylcellulose and $0.2 \mathrm{ml} /$ mouse and delivered by gavage with a dose of $3.1 \mathrm{mg} / \mathrm{kg}$ according to the treatment schedule (Table 3).

Table 3. Treatment schedule to reflect preventive and curative modes. *

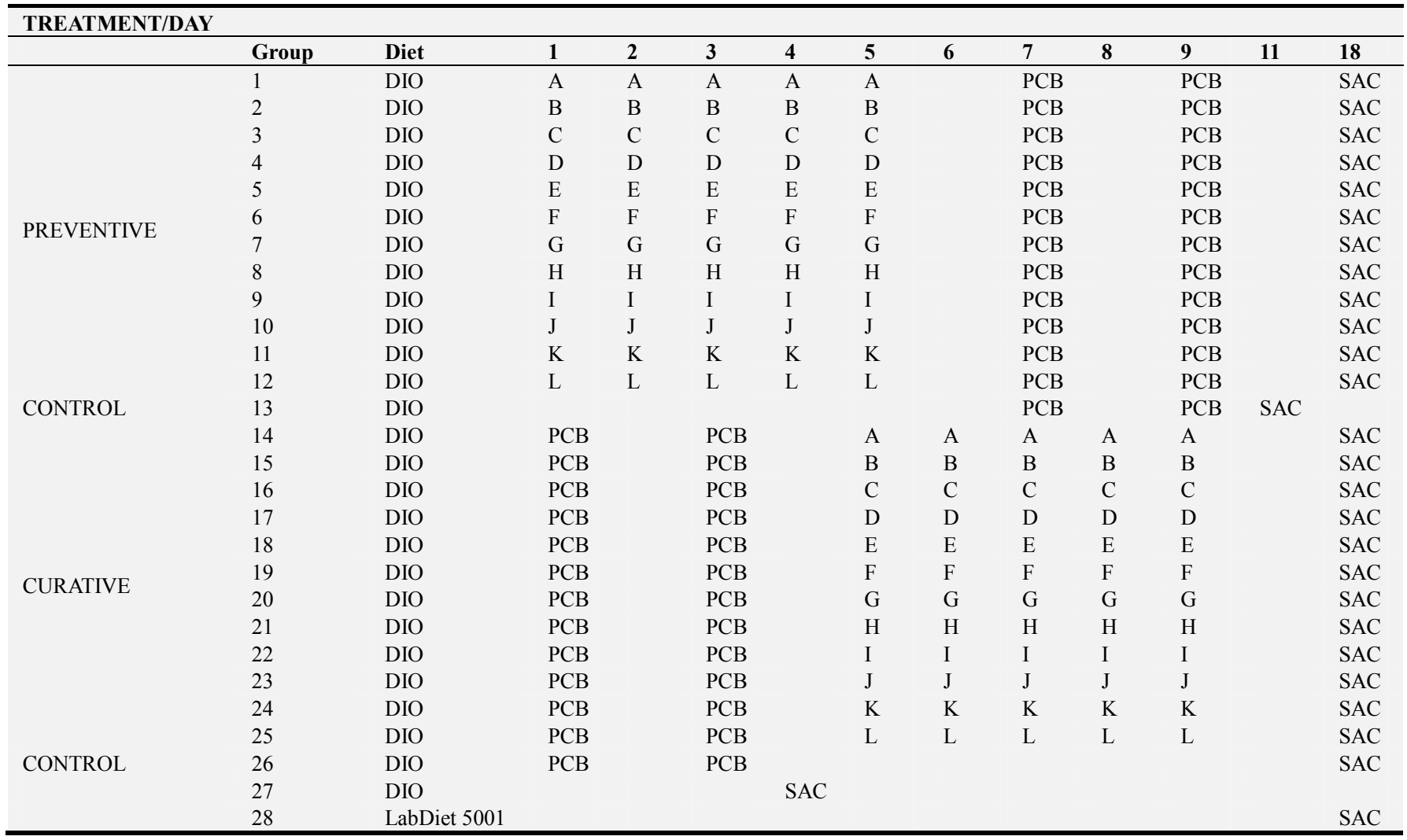

* DIO (high fat diet)

A-L (3-NCE combos)

PCB (polychlorobiphenyl)

SAC (sacrifice, harvest)

\subsection{Enzyme-linked Immunosorbent Assay (ELISA)}

ELISA is a blood test that detects an antigen, and in this study the chosen antigens were debris or detritus from disrupted GCX. Previous work [125] showed high correlation of plaque formation to elevated ELISA values on 4 biomarkers including Heparan Sulfate (HS), Hyaluronan Synthase 1 (HAS-1), Syndecan 1 (SDC1), and total Plasminogen Activation Inhibitor-1 (PAI-1). These biomarkers are used as a 4-panel diagnostic 'fingerprint' to evaluate the curative or preventive effect of the therapeutic compounds: preventive (PCB added day $7 \& 9$ to 16 -day old 
mice on fat diet, then therapeutics added daily, 1 thru 5); curative (PCB added days $1 \& 3$ to 16-day mice on fat diet, then drugs added daily, 5 thru 9).

HS and HAS-1 kits were obtained from Antibodies-Online (Limerick, PA) SDC-1 from USCN (Houston, Texas) and PAI-1 from Molecular Innovations (Novi, MI). All tests were performed on plasma, diluted to the fall within the standard curve if necessary, and carried out according to the manufacturer's instructions. All tests were performed on plasma, diluted to fall within the standard curve, and carried out according to the manufacturer's instructions.

\subsection{Statistical Analysis}

Data presented as the standard error of the mean (SEM) and ANOVA used for analysis. A $P$ value $<0.05$ was considered significant.

\subsection{Sacrifice and Harvest}

The mice were sacrificed on days 4,11 , or 18 according to the experimental plan (three each from groups). The animals were anesthetized by intraperitoneal injection of $90 \mathrm{mg} / \mathrm{kg}$ Ketamine and $8 \mathrm{mg} / \mathrm{kg}$ Xylazine, and Isoflurane gas anesthesia. Blood was collected by retro-orbital bleeding or from the heart and mixed with $50 \mathrm{mg} / \mathrm{ml}$ heparin to prevent clotting. The thorax was opened to expose the heart, and saline was injected into the left ventricle, with the right atrium opened to allow the drainage of blood and saline. The heart was perfused with at least $5 \mathrm{ml}$ of saline and until no blood was observed in the drainage from the atrium. The heart was carefully dissected and frozen for histological sectioning. Plasma was collected from the blood samples by centrifuging at $1000 \mathrm{rpm}$ for 15 minutes and collecting the supernatant. The samples were stored at $-80^{\circ} \mathrm{C}$ until analysis.

\section{Results}

\subsection{Toxicology}

No mice died during the study, and no adverse effects were noted due to administration of either the PCB or drug suspensions. No notable gross pathology changes were noted attributable to the therapeutic compounds.

\subsection{Drug Targets and Synthesized Compounds}

Understanding the disease cascade and recognizing dysfunctional sites is key to designing drugs. The main pathogenetic mechanism in CVD is thromboembolism, thus a conceptual thromboembolic cascade was constructed and identified 5 druggable targets (Figure 5).

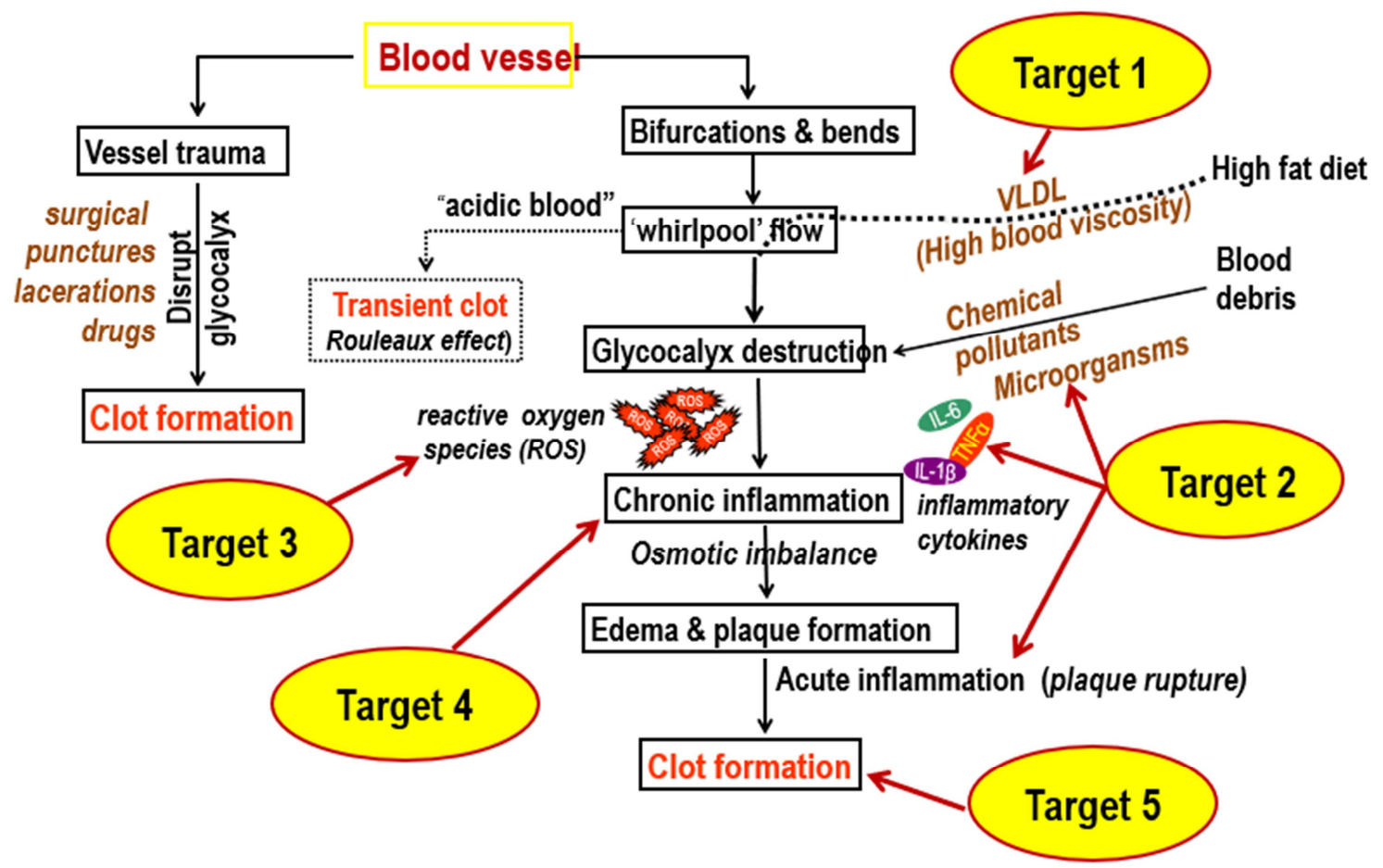

Figure 5. A virtual thromboembolic cascade and possible "druggable" sites.

\subsection{Synthesis of Compounds for Druggable Targets}

8 new chemical entities (NCEs) were rationally synthesized for the corresponding targets: FTX-214, -216, -$218,-219,-224,-226,-229,-230$. Synthesis of these NCEs was based on empirical knowledge of active drug scaffolds and mode of action to address the indicated targets. Since no single NCE could address in toto the thromboembolic cascade, a combo-compound therapy was the best option. Thus, an abbreviated 3-factor permutation combination was carried out on the 8 NCEs, which resulted in twelve 3-NCE combos (A-L), hereafter called 'combo compound or 
combo'. The combos were formulated at a fixed dose 1: 1: 1 ratio. The structures of the NCEs designated as FTX and the
3-NCE combos are shown in Figure 6.

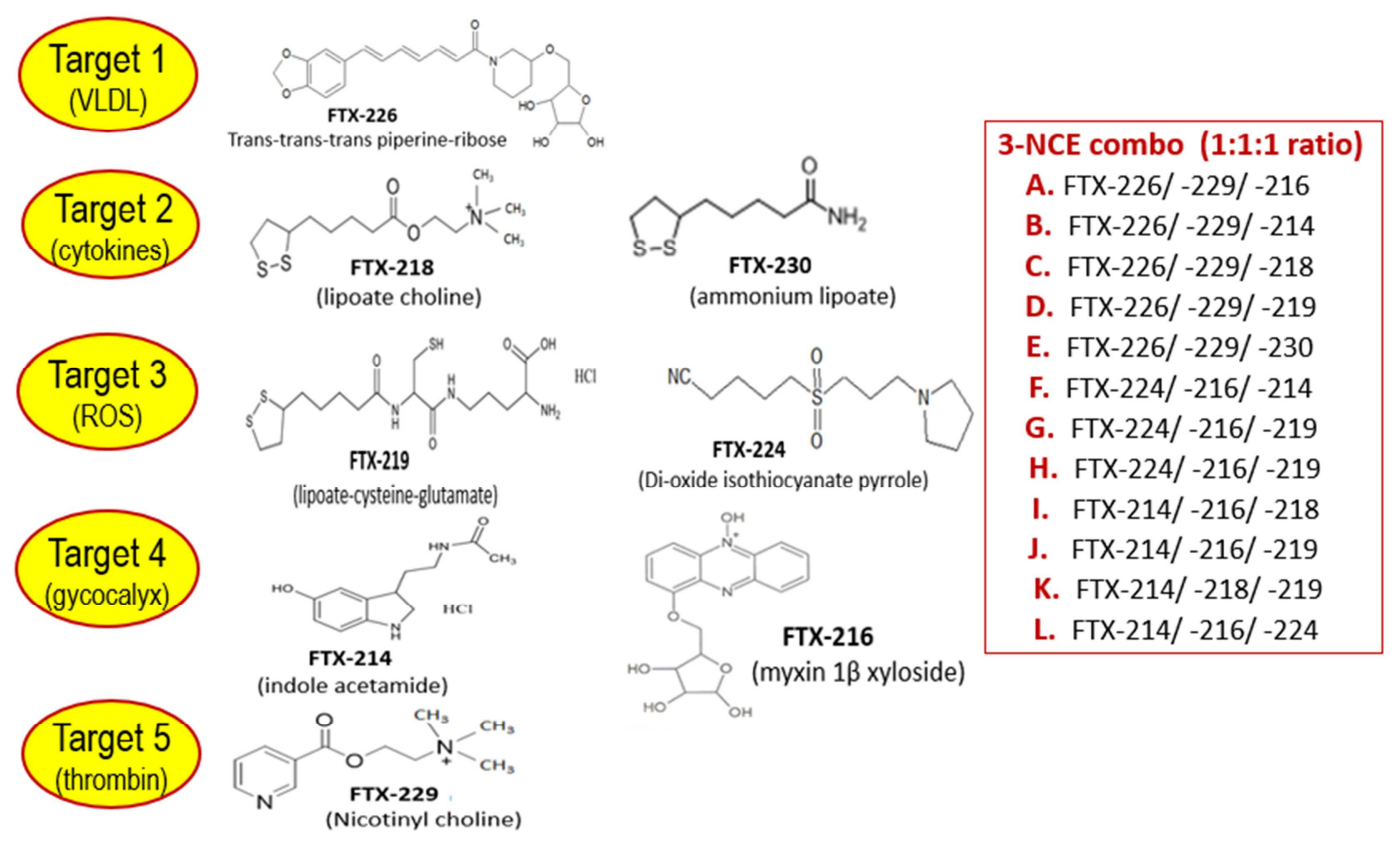

Figure 6. Structures of 8 new chemical entities (NCES), targets, and components of 3-NCE combos (A-L).

\subsection{ELISA Values}

Statistical analyses were carried out to determine the correlation of ELISA data and the preventive or curative effect of the combos. A small p-value (typically $\leq 0.05)$ indicates strong correlation; a large p-value $(>0.05)$ indicates weak relationship (Table 4).

Table 4. Statistics for biomarker assays ( $p$ values).

\begin{tabular}{|c|c|c|c|c|c|c|}
\hline Protocol & Combo & Group & HAS-1 & HS & PAI-1 & SDC-I \\
\hline \multirow{5}{*}{ PREVENTIVE } & $\mathrm{A}$ & 1 & 0.439 & .652 & .552 & 0.023 \\
\hline & B & 2 & 0.833 & .337 & .023 & 0.771 \\
\hline & $\mathrm{C}$ & 3 & 0.931 & .556 & .224 & 0.100 \\
\hline & $\mathrm{D}$ & 4 & 0.700 & .291 & .006 & 0.982 \\
\hline & $\mathrm{E}$ & 5 & 0.983 & .051 & .012 & 0.015 \\
\hline \multirow{19}{*}{ PREVENTIVE } & $\mathrm{F}$ & 6 & 0.979 & .003 & .015 & 0.455 \\
\hline & G & 7 & 0.181 & .041 & .572 & 0.314 \\
\hline & $\mathrm{H}$ & 8 & 0.849 & .010 & .008 & 0.655 \\
\hline & I & 9 & 0.470 & .001 & .003 & 0.815 \\
\hline & $\mathrm{J}$ & 10 & 0.920 & .122 & .001 & 0.570 \\
\hline & $\mathrm{K}$ & 11 & 0.184 & .004 & .091 & 0.942 \\
\hline & $\mathrm{L}$ & 12 & 0.938 & .001 & .015 & 0.572 \\
\hline & A & 14 & 0.009 & .417 & .001 & 0.713 \\
\hline & $\mathrm{B}$ & 15 & 0.002 & .115 & .001 & 0.772 \\
\hline & $\mathrm{C}$ & 16 & 0.004 & .037 & .001 & 0.370 \\
\hline & $\mathrm{D}$ & 17 & 0.232 & .233 & .001 & 0.491 \\
\hline & $\mathrm{E}$ & 18 & 0.202 & .077 & .001 & 0.490 \\
\hline & $\mathrm{F}$ & 19 & 0.002 & .138 & .469 & 0.641 \\
\hline & G & 20 & 0.083 & .792 & .001 & 0.588 \\
\hline & $\mathrm{H}$ & 21 & 0.065 & .844 & .001 & 0.542 \\
\hline & I & 22 & 0.004 & .186 & .001 & 0.245 \\
\hline & $\mathrm{J}$ & 23 & 0.003 & .254 & .055 & 0.646 \\
\hline & $\mathrm{K}$ & 24 & 0.003 & .315 & .001 & 0.345 \\
\hline & $\mathrm{L}$ & 25 & 0.066 & .730 & .001 & 0.574 \\
\hline
\end{tabular}

There are three untreated controls: 'normal' (regular diet), 'DIO' (high-fat diet) and 'none' (high-fat diet + PCB). The normal and DIO reflect the baseline level of biomarkers indicative of normal turnover or shedding of these GCX components. Taking the average ELISA values of these 2 controls, the turnover rate is as follows: PAI-1 (2,096 
$\mathrm{pg} / \mathrm{ml})>\mathrm{HS}(106 \mathrm{pg} / \mathrm{ml})>\mathrm{SDC}-1(66 \mathrm{pg} / \mathrm{ml})>\operatorname{HAS}(19$

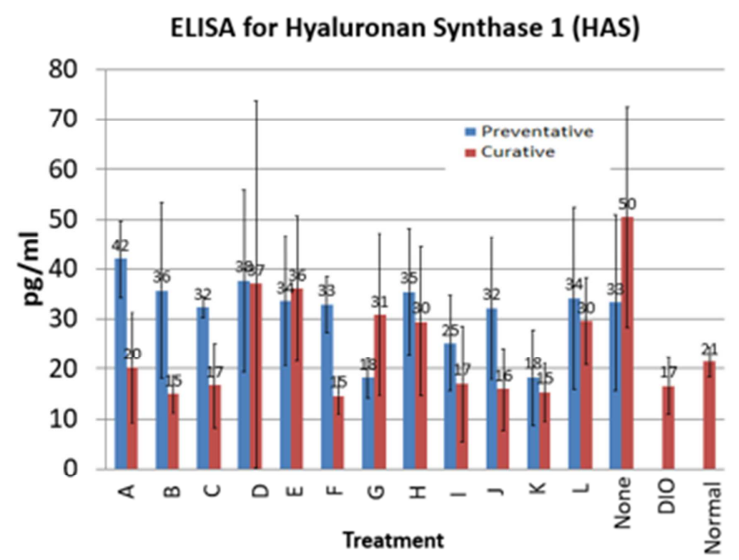

ELISA for Plasminogen Activation Inhibitor-1 (PAI-1)

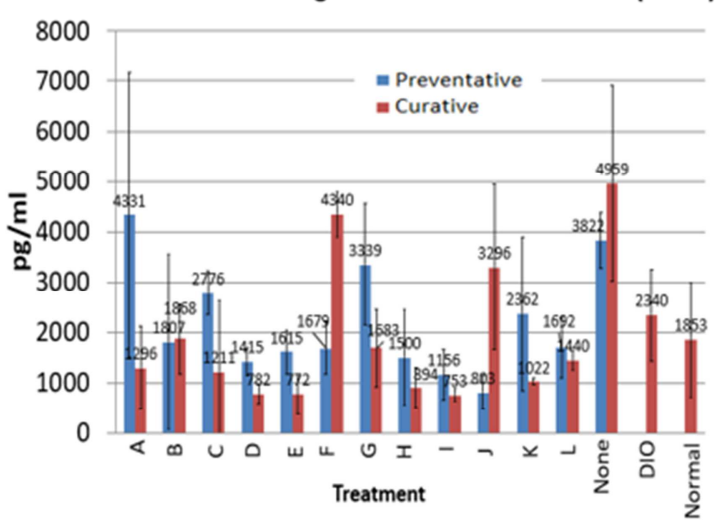

pg/ml) (Figure 7).
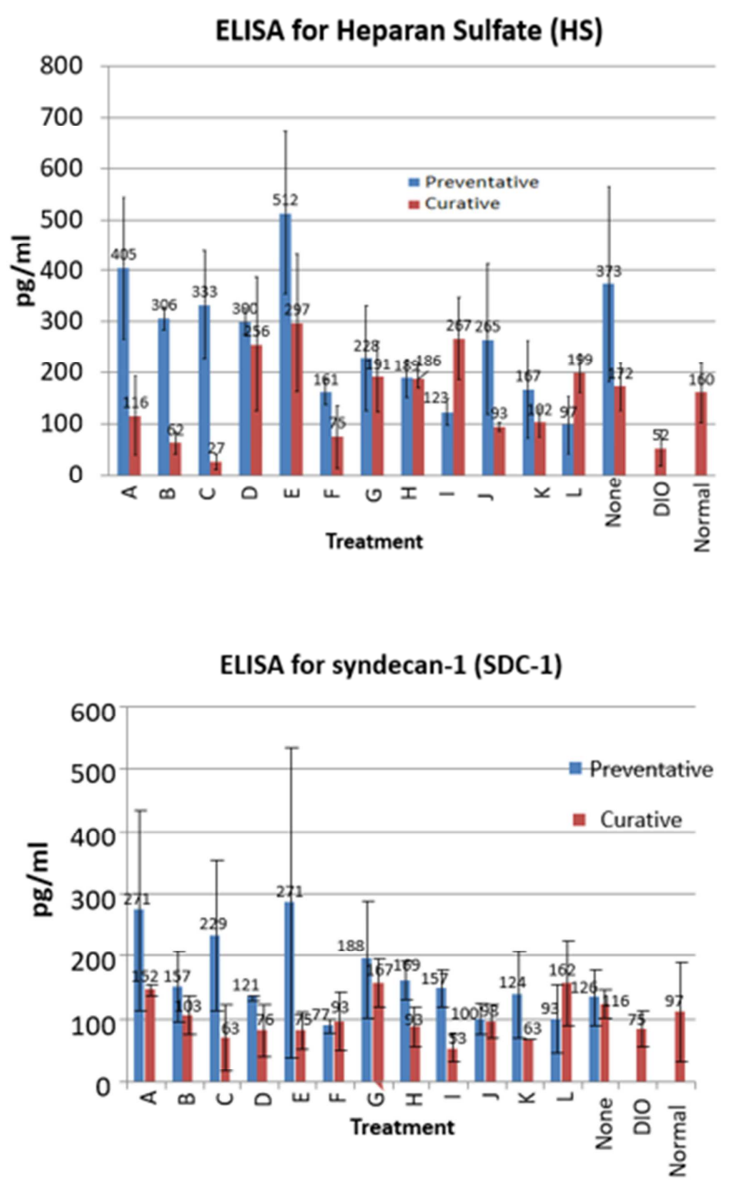

Figure 7. Response profiles of the 4 biomarker to 3-NCE combo treatment.

The $3^{\text {rd }}$ control are mice fed with high fat diet and gavaged with the PCB pollutant. This control group was subdivided in two to provide baseline reference point for "preventive" as well as "curative". Thus, ELISA biomarker level of a combotreated mouse is subtracted from the corresponding control to give the net therapeutic activity. In this regard, the therapeutic activities of the combo compound are reflected by the reduction in ELISA values:

\subsubsection{Hyaluronan Synthase (HAS-1)}

Reduced levels were observed in mice treated with Combos G, I and $\mathrm{K}$ in the Preventative Protocol, and Combos A, B, C, F, I, J, K and L in the Curative Protocol. ANOVA statistics for the comparison of levels revealed no significant changes in the Preventative Protocol, with trends $(p=0.18)$ for both Combos G and K. Statistical differences were observed for Combos A, B, C, F, I, J, and K in the Curative Protocol and ranged from $\mathrm{p}<0.002$ to $\mathrm{p}<0.01$.

\subsubsection{Heparan Sulfate (HS)}

Reductions in HS levels were observed in mice treated with Combos F, G, H, I, K and L in the Preventive Protocol, and Combos A, B, C, F, J, and $\mathrm{K}$ in the Curative Protocol. ANOVA statistics for the comparison of levels revealed significant changes in the Preventative Protocol, with decreases due to Combos $F, G, H, I, K$ and $L$ ranging from $\mathrm{p}<0.05$ to $\mathrm{p}<0.001$.

\subsubsection{Total Plasminogen Activation Inhibitor-1 (PAI-1)}

Reductions in PAI-1 levels were observed in mice treated with Combos B, D, E, F, H, I, J, K and L in the Preventive Protocol, and all Combos except $\mathrm{F}$ and $\mathrm{J}$ in the Curative Protocol. ANOVA statistics for the comparison of levels revealed significant changes in the Preventive Protocol, with decrease due to Combos B, D, E, F, H, I, J and L ranging from $\mathrm{p}<0.02$ to $\mathrm{p}<0.001$.

\subsubsection{Syndecan1 (SDC1)}

Reductions in SDC1 levels were observed in mice treated with Combos D, F, J, and $\mathrm{K}$ in the Preventive Protocol, and Combos B, C, D, E, F, H, I, J, and K in the Curative Protocol.

\subsection{Summary of Therapeutic Activities}

\subsubsection{Combo Preventive and Curative Activity Ratings}

The therapeutic effect of the 12 combos (A-L) vs the 4panel biomarker is presented in numerical format (Table 5) as well as graphics (Figure 8). 
Table 5. Comparative activities of the 12 (A-L) 3-NCE combos showing inactive (red) and active values per ELISA levels.

\begin{tabular}{|c|c|c|c|c|c|c|c|c|c|}
\hline \multicolumn{10}{|c|}{ Blood Markers (ELISA: pg/ml) } \\
\hline \multirow{2}{*}{\multicolumn{2}{|c|}{ 3-NCE combo (FTX) }} & \multicolumn{2}{|c|}{ Hyaluronan (HAS) } & \multicolumn{2}{|c|}{ Heparan SO4 (HS) } & \multicolumn{2}{|c|}{ Plasminogen (PAI-1) } & \multicolumn{2}{|c|}{ Syndecan-1 (SDC-1) } \\
\hline & & Preventive & curative & Preventive & curative & Preventive & curative & Preventive & curative \\
\hline A & $226 / 229 / 216$ & 40 & 20 & 405 & 116 & 4331 & 1296 & 271 & 152 \\
\hline B & $226 / 229 / 214$ & 36 & 15 & 305 & 52 & 1807 & 1868 & 157 & 103 \\
\hline $\mathrm{C}$ & $226 / 229 / 218$ & 32 & 27 & 333 & 27 & 2776 & 1211 & 229 & 63 \\
\hline D & $26 / 229 / 219$ & 38 & 37 & 300 & 156 & 1415 & 782 & 121 & 76 \\
\hline E & $226 / 229 / 230$ & 34 & 36 & 512 & 297 & 1615 & 772 & 271 & 75 \\
\hline $\mathrm{F}$ & $224 / 216 / 214$ & 33 & 15 & 161 & 75 & 1679 & 4340 & 77 & 93 \\
\hline G & $224 / 216 / 219$ & 18 & 31 & 228 & 191 & 3339 & 1683 & 188 & 167 \\
\hline $\mathrm{H}$ & $224 / 216 / 219$ & 35 & 30 & 189 & 186 & 1500 & 894 & 169 & 93 \\
\hline I & $214 / 216 / 218$ & 25 & 17 & 123 & 267 & 1156 & 753 & 157 & 53 \\
\hline $\mathrm{J}$ & $214 / 216 / 219$ & 32 & 16 & 265 & 93 & 803 & 3296 & 100 & 98 \\
\hline $\mathrm{K}$ & $214 / 218 / 219$ & 18 & 15 & 167 & 102 & 2362 & 1022 & 124 & 63 \\
\hline E & $214 / 216 / 224$ & 34 & 30 & 97 & 199 & 1692 & 1440 & 93 & 162 \\
\hline \multicolumn{2}{|c|}{ Control (no combo) } & 33 & 50 & 373 & 172 & 3822 & 4959 & 126 & 116 \\
\hline
\end{tabular}

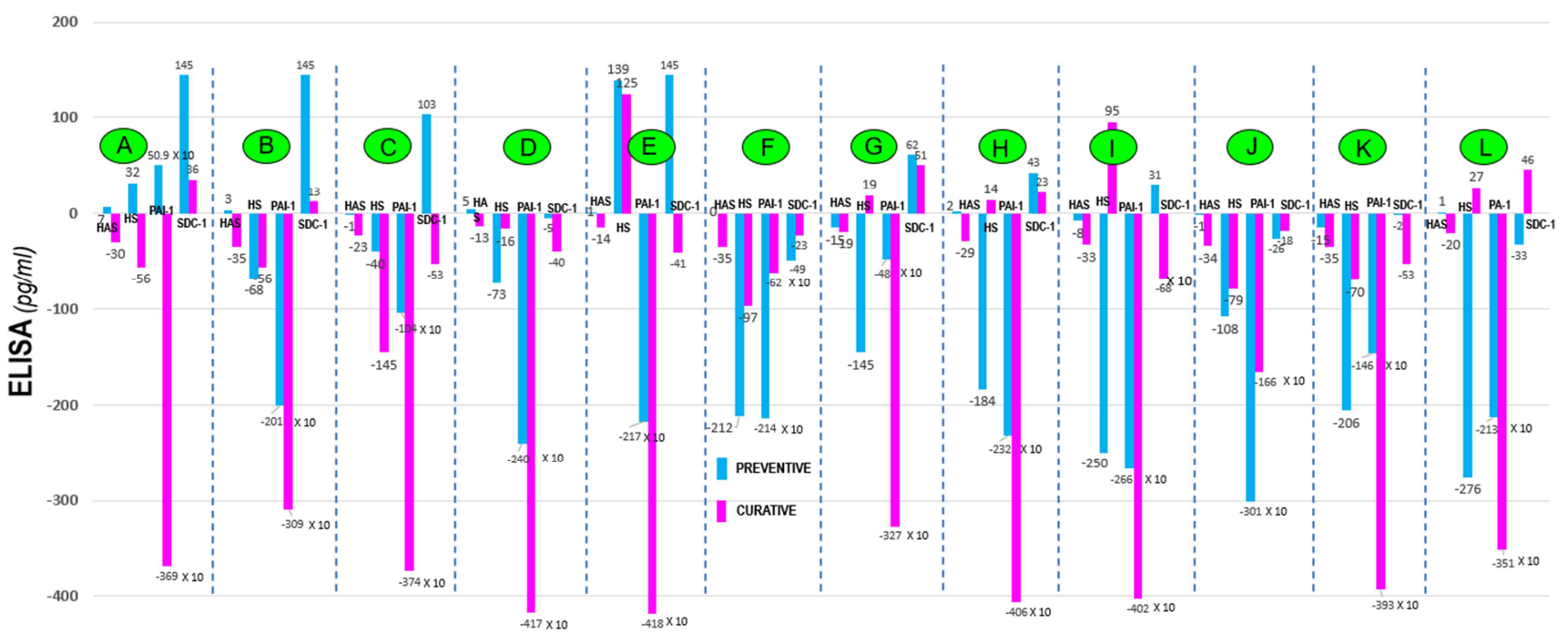

Figure 8. Graphical presentation of the preventive and/or curative activities of the 12 (A-L) 3-NCE combos per 4-panel ELISA levels. Combos D, F, J and $K$ show both preventive and curative activities.

A combo that did not reduce biomarker level (red) is considered inactive (Table 5), which is represented as "positive" bars in Figure 8. Combos D, F, J and $\mathrm{K}$ were preventive and curative. Combo A was predominantly curative (except vs SDC-1); on the other hand, there was no combo found to be selectively preventive. Combo $\mathrm{K}$ was chosen for further evaluation because of its overall superior profile $(\mathrm{K}>\mathrm{J}>\mathrm{F}>\mathrm{D})$ and hereby designated Embotricin ${ }^{\mathrm{TM}}$

\subsubsection{NCE Activity Rating}

Individual NCEs showed inherent activities with the following order based on frequency of appearance in the active combo. For example, the individual components of combos $\mathrm{K}, \mathrm{J}, \mathrm{F}$ and $\mathrm{D}$, which were curative/preventive of plaques are ranked as follows (frequency): FTX-214 (3) > FTX-219 (3) > FTX-216 (2) > FTX-218 (1)=FTX-224 (1)=FTX-226 (1)=FTX-229 (1). The targets in order of significance follows: GCX repair $($ FTX-214, -216) $=$ ROS $($ FTX-219, - 224) $>$ inflammation $($ FTX-218) $=$ VLDL (FTX226) $=$ thrombin $($ FTX-229).

\subsection{Histopathology}

While the curative and or preventive effects of the combos were evaluated by ELISA, presence of plaque was confirmed by histopathology, particularly in the brachiocephalic artery. Typical histopathology shows plaque formation in the control (no NCE treatment) while no plaques in the combo treatment. For example, the control animals (High fat diet, PCB) showed plaques typically with a fibrous material loosely attached to the surface of the arterial wall (Figure 9A, 9B). In contrast, the combo treated animals including Embotricin ${ }^{\mathrm{TM}}$ exhibited the typical features of a normal arterial wall (Figure 9C). 


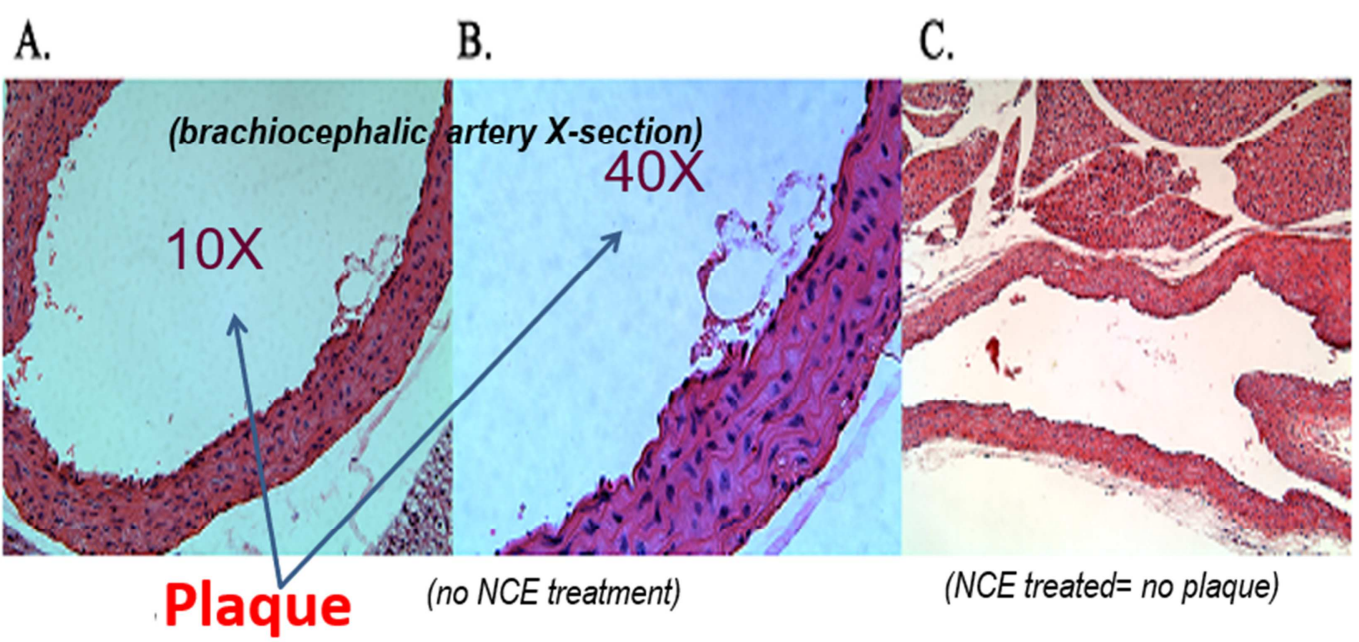

Figure 9. A plaque produced in the TAP mouse located in the subendothelial region with fibrous cap similar to human.

Other histopathological features in the control animals showed various lesion stages including lipid deposits, fatty streaks and eventually a well-defined plaque with fibrous cap (Figure 10c).

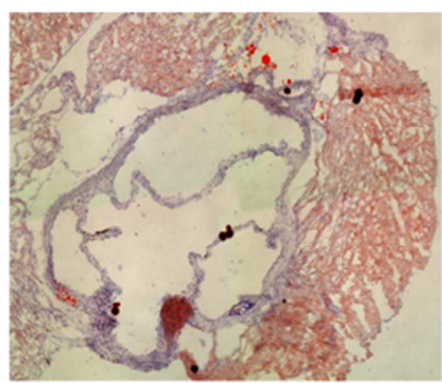

A. Inflamed areas with lipid deposits

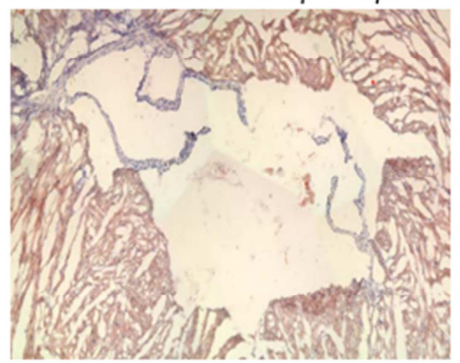

D. Small fatty plaque $(100 x)$

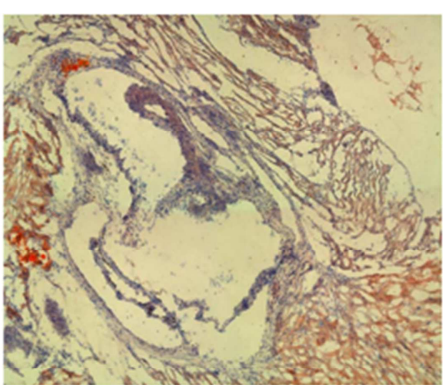

B. Sinus wall with lipid staining

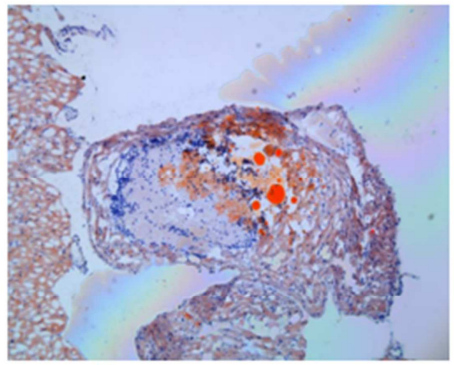

E. Plaque (100x)

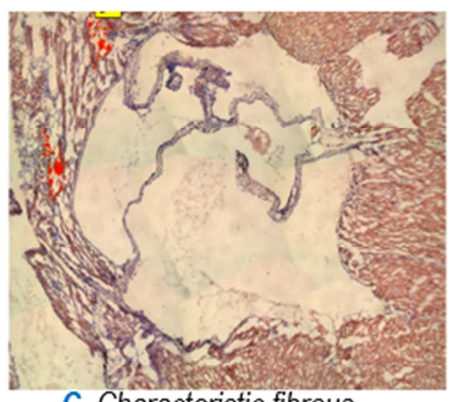

C. Characteristic fibrous

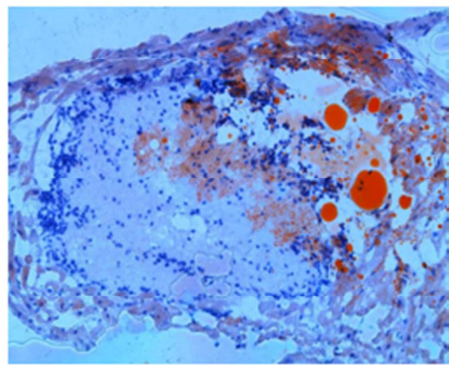

F. Plaque $(200 x)$

Figure 10. Stages of lesion development in the TAP mouse model including lipid deposits fatty streaks and eventually a well-defined fibrous cap.

\section{Discussion}

\subsection{Drug Discovery Paradigms}

The traditional drug development strategy is based on the 'one gene-one disease' paradigm, searching for a target gene to develop a 'magic-bullet'. This paradigm assumes that a disease is caused by dysfunctional gene, which inspired the mapping of the human genome to identify mutant genes [167], and the evolution of the 4 "omics", including genomics (DNA, RNA), proteomics (proteins), metabolomics (metabolites) and glycomics (sugars) to classify target genes [168]. A gene is the basic unit of heredity defined by a specific nucleotide sequence, which is studied under genetics and epigenetics. While genetics study genes that alter genetic material to control functions, epigenetics study modification of gene expression due to acquired "ornamentations" including DNA methylation, histone modification, RNA acetylation, etc. [169]. These epigenic "ornamentations" are triggered by extraneous factors, stress, and drugs [170]. For example, $>90 \%$ of disease risks are epigenetic in nature [12], which accounts for sporadic cancer [171] and CVD [172].

The G protein-coupled receptor (GPCR) represent the largest protein family encoded by the human genome and the most prominent gene target for therapeutic agents [173]. There are 2350 epigenetic "mutations" attributed to GPCRs from which over 66 human diseases have been identified [174] and over 160 GPCR genes are being evaluated as drug targets in mice [175]. GCPRs are nested in the GCX of the 
cell membrane, which binds extracellular substances and transmits signals to an intracellular molecule called a $G$ protein (guanine nucleotide-binding protein) [176]. GCX disruption affects the GPCRs downstream signaling pathways and the enzymes associated with these downstream pathways are the targets of drug development [177]. These are epigenetics in nature and could be temporary, occur during a lifetime, or heritable [178]. In this regard, genetics and epigenetics crisscross each other complicating the understanding of disease etiology [179]. Even FH, a genetic variant in LDLR, APOB, or PCSK9, now reveals major DNA methylation patterns characteristic of epigenetics [180]. Also, effect of fatty acid diet is now found to have epigenetic mechanism on CVD and other chronic diseases [181].

At the molecular level, epigenetic changes involve the "ornamentations" within the nucleic acids and histone proteins. These "ornamentations" consist of three families of proteins including "writers", "reader" and "erasers", which are druggable targets. For example, "writers" are enzymes that add ornamentation, "readers" control binding of such enzymes and "erasers" regulates reversibility of both writers and readers [182]. Drugs that target ornamentations are called epidrugs [183] with a global market of $\$ 7.50$ billion in 2019 and grows to $\$ 31.64$ billion by 2027 [172, 184, 185], which includes inhibitors of DNA methyltransferase, histone deacetylase (HDAC), histone methyltransferase, lysine demethylase. As monotherapies these inhibitors modulate downstream effects of these enzymes, but they do not treat the disease in toto [186]. Identifying and targeting the multitude GPCR genes is an iteration of the 'one gene-one enzyme/disease' drug discovery platform, which has not delivered the promised "magic bullet".

Key to the success of a drug development program is understanding the upstream disease etiology. This study recognizes that vascular diseases including CVD are triggered by extraneous (xeno) factors, which is of multiple (plexic) origin including environment, lifestyle, and drug usage, herein called xenoplexic diseases. Xenoplexic diseases are pathologies resulting from upstream cell disruptions and if left unrepaired becomes a downstream chronic pathology manifested in different symptoms. In this regard the complicit etiology of xenoplexic diseases is best treated with combo drugs, while the monotherapy platform targeting symptoms is at best palliative and not curative. CVD is an example of xenoplexic disease as illustrated in Figure 11.

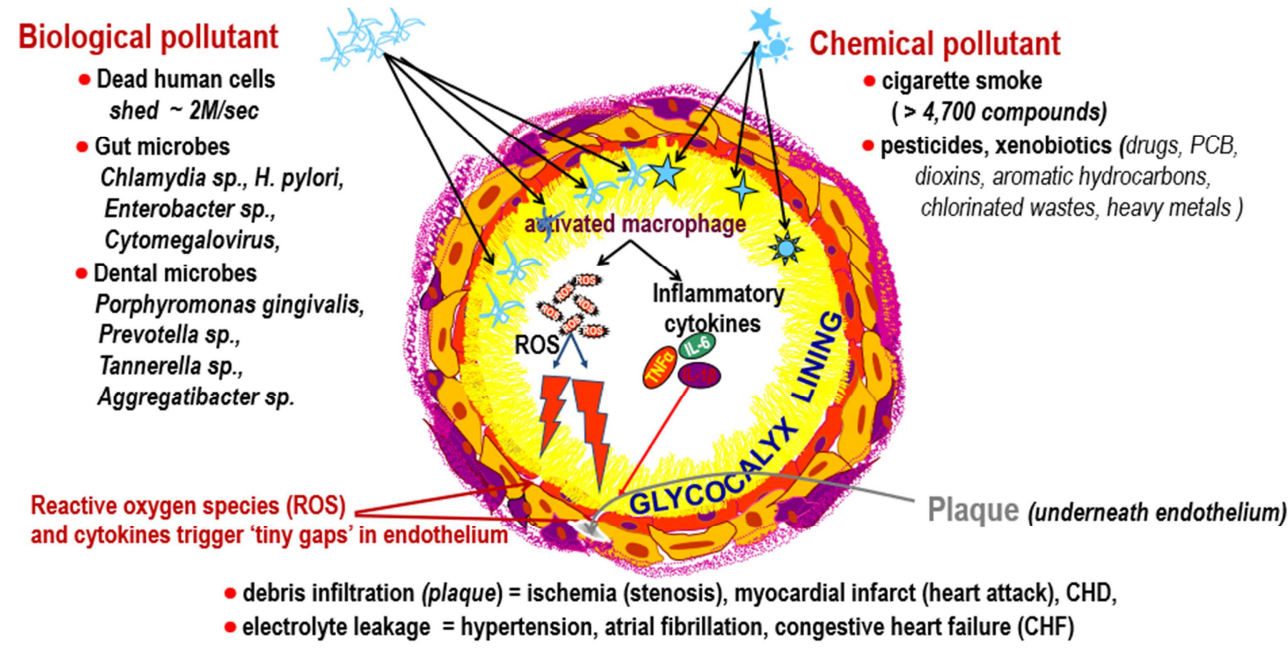

Figure 11. Biological and chemical pollutants in the arterial bends trigger inflammation, tiny endothelial gaps creating electrolyte leakage (hypertension) and debris infiltration (plaque).

\subsection{Combo Drug Therapy}

The one-gene one enzyme or the polypharmacology approach [187] to treating CVD has failed. Targeting a single step along a given pathway or even targeting a single pathway does not effectively treat a complex disease like CVD. Developing combinations simultaneously, rather than as individual entities is a more effective approach to treat disease progression typical of a xenoplexic disease.

\subsection{Mouse and Humans}

Mouse and humans share close genomic homologies, whereby only less than $1 \%$ of the wild type C57BL/6 mouse, genes do not have any detectable homologue in the human genome [188]. Mice are naturally resistant to atherosclerosis but produce arterial lesions when fed with high-fat/high-cholesterol diets supplemented with cholic acid (CA) [189]. Several studies have varied the ratios of fat, cholesterol and cholic acid to obtain persistent hypercholesterolemia of $>300 \mathrm{mg} / \mathrm{dL}$ cholesterol, which account for cholesterol lesions; but are not typical or predictive in humans [190]. KO mice model of hypercholesterolemia also produced fatty streaks not comparable to the human plaques produced on the high fat "Western" diet [191]. This study used a wild mouse exposed to the xenoplexic factors as humans and, indeed, produced plaques with fibrous caps like humans. 


\subsection{Biomarkers of CVD and Drug Development}

A biomarker can be a gene, a gene mutation, protein, other molecule, or clinical measurement that indicates a given disease state. Single markers, while clinically appealing due to simplicity and low cost, do not capture the complicit nature of xenoplexic disease, which makes them inaccurate, insensitive, and non-specific. To improve the prediction of death from cardiovascular causes, a combination of biomarkers including troponin, natriuretic peptide, cystatin C, C-reactive protein was proposed [192]. In this study, the components and sequela of GCX disruption were chosen as a diagnostic panel including: Hyaluronan synthase (HAS-1), Heparan sulfate (HS). Total Plasminogen Activation Inhibitor-1 (PAI-1) and Syndecan1 (SDC1).

It appears that as the GCX is disrupted the endothelium releases an embedded protein called plasminogen activator inhibitor-1 (PAI-1); this protein mainly produced by the endothelium suppress fibrinolysis or hemorrhaging; heparan sulfate is found in the outermost layer of the protective glycocalyx and the first to be shed when the shield is compromised. As disruption advances, syndecan -1 (Syn-1), which maintain cytoskeletal integrity is shed, followed by hyaluronan, a glyocosaminoglycan that abuts the heparan sulfate. These biomarkers have been used in the clinic as single markers with limited success, but the failure of individual markers is that in a xenoplexic disease a mixture of these biomarkers is present in the milieu at any given time in different levels. Thus, picking one biomarker does not reflect the dynamic process, which lowers its diagnostic or predictive capacity. Thus, a panel of biomarkers used as a "fingerprint" is a more appropriate diagnostic tool for xenoplexic diseases like CVD.

\subsection{The Significance of This Study}

The integrity of the GCX is maintained by a balanced synthesis and shedding of its component parts. While excess shedding is associated with cardiovascular risks, it is possible to stop excess shedding and maintain a homeostatic balance. Embotricin $^{\mathrm{TM}}$ restores the integrity of the GCX because of its combo compound components as evidenced by plaque prevention and reversal. Death of patients with CHD is due to disruption of an atherosclerotic plaque with subsequent complete or partial vascular thrombosis [193]. The presence of plaque is the hallmark of coronary atherosclerosis and a prerequisite for increased acute coronary events [194] and risk of death increases with the extent of plaques [195]. Even though most plaque disruptions do not lead to acute coronary events, some do and the more plaques that are present the more plaque disruptions occur and the greater the probability that one of them triggers vascular thrombosis [196]. The robust preclinical data of Embotricin ${ }^{\mathrm{TM}}$ effectively targeting plaque may well be the first curative (anti-embolic ${ }^{\text {TM }}$ drug against CVD with the same impact as penicillin to infectious disease.

\section{Conclusion}

The proposed mode of action (MOA) of Embotricin ${ }^{\mathrm{TM}}$ is a synergy of its component compounds (Figure 12): FTX-214 upregulate aryl hydrocarbon receptor (AhR) and triggers multigene expressions including xenobiotic metabolizing enzymes [e.g., cytochrome P450 (CYP) 1A1, B1], extracellular matrix synthesis, cholesterol biosynthesis and cell signaling at the cell membrane [197]. AhR deficiency triggers inflammation and disrupts matrix biology resulting in diseases [198]. FTX-218 binds with the oxidized Nrf2Keap-1 complex and release NRF2. Nrf2 subsequently transcribe the genes to produce a myriad of antioxidant enzymes including, Glutathione transferase (GST), Glutathione synthetase (GS), Glutathione peroxidase (GPx), Superoxide dismutase (SOD), Catalase (CAT), to protect cell from free radicals $(\mathrm{R} \cdot)$ and other reactive oxygen species (ROS) [199, 200].

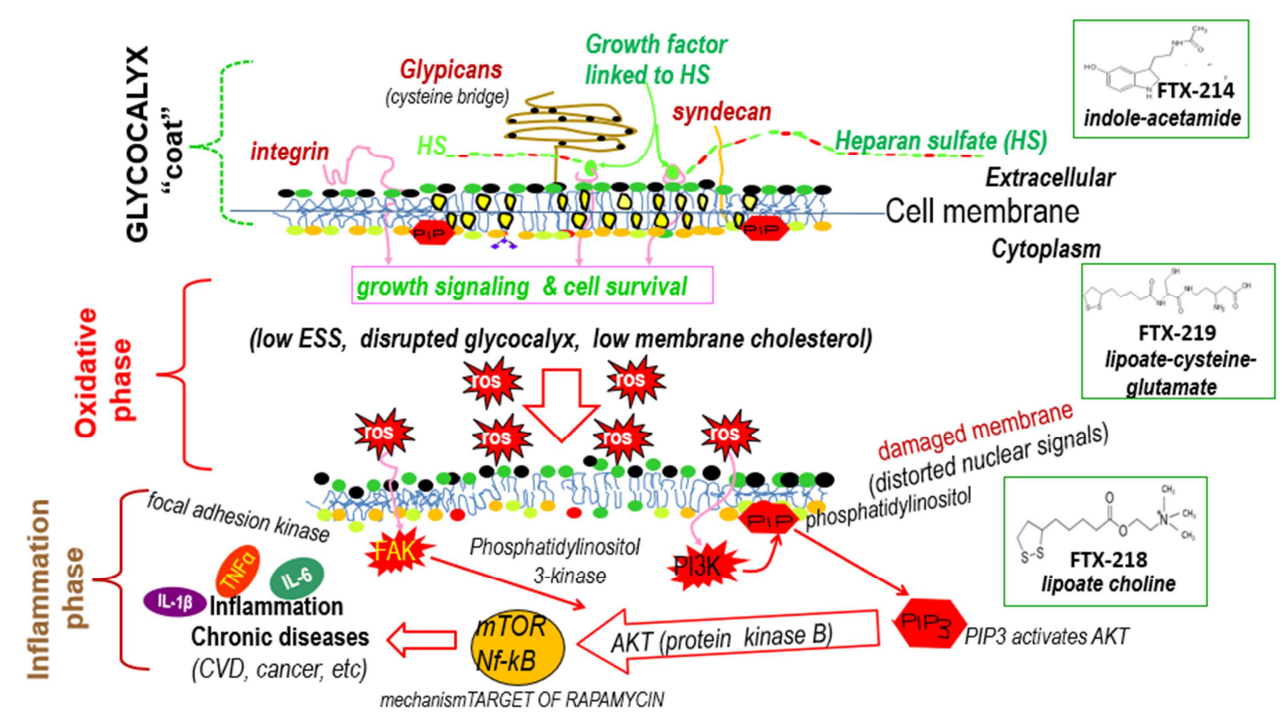

Figure 12. Proposed molecular mode of action of the three NCE components of Embotricin ${ }^{\mathrm{TM}}$ 
FTX-219 inactivates the nuclear factor kappa B (NF-kB), which is a crucial to various biological processes, including immune response, inflammation, cell growth and survival, and development [201, 202], NF-kB is activated during oxidative stress [203] triggering inflammatory responses [204].

\section{Conflicts of Interest}

The author declares no competing interest.

\section{Acknowledgements}

The author would like to thank Dr. Paul Wooley and his staff for tending the animals and carrying out the histopathology and ELISA at Wichita State University, Wichita, KS 67214.

\section{References}

[1] Institute of Medicine (US) Committee on a National Surveillance System for Cardiovascular and Select Chronic Diseases. A Nationwide Framework for Surveillance of Cardiovascular and Chronic Lung Diseases (2011) Washington (DC): National Academies Press.

[2] Dhami, N. "Trends in Pharmacognosy: A modern science of natural medicines". Journal of Herbal Medicine (2013) 3 (4): 123-131.

[3] Waring MJ, Arrowsmith J, Leach AR, Leeson PD, Mandrell S, Owen RM, Pairaudeau G, Pennie WD, Pickett SD, Wang J, Wallace O, Weir A. An analysis of the attrition of drug candidates from four major pharmaceutical companies. Nat Rev Drug Discov. (2015) 14 (7): 475-86.

[4] Gould K. Antibiotics: from prehistory to the present day, J Antimicrob Chemother (2016) 71 (3): 572-575.

[5] Tunac, J. B. Microorganisms, Strategic sources of novel antitumor agents. In Anticancer Drug Discovery and Development: Natural Products and New Molecular Models, eds F. Valeriote, T. Corbett, \& L. Baker. Kluwer Acad. Publishers. Boston/Dordrecht/London. [http://www.wkap.nl/prod/b/0-7923-2928-7?a=1.

[6] Dan VM, Sanawar R. Anticancer Agents from Microbes. In: Sugathan S., Pradeep N., Abdulhameed S. (eds) Bioresources and Bioprocess in Biotechnology. Springer, Singapore (2017) 171-184. https://doi.org/10.1007/978-981-10-4284-3.

[7] Horowitz NH. "The sixtieth anniversary of biochemical genetics". Genetics (1996) 143 (1): 1-4.

[8] Endo A, Kuroda M, Tsujita Y. "ML-236A, ML-236B, and ML-236C, new inhibitors of cholesterogenesis produced by Penicillium citrinium". J Antibiotics (1976) 29 (12): 1346-8.

[9] Hopkins AL, Groom CR. The Druggable Genome. Nature Reviews Drug Discovery (2002) 1 (9): 727-30.

[10] Shadyab AH, LaCroix AZ. Genetic Factors associated with longevity: a review of recent findings, Ageing Research Reviews (2015) 19: 1-7.

[11] Lichtenstein P, Holm NV, Verkasalo PK, Iliadou A, Kaprio J, Koskenvuo M, Pukkala E, Skytthe A, Hemminki K.
Environmental and heritable factors in the causation of cancer--analyses of cohorts of twins from Sweden, Denmark, and Finland. N. Engl. J. Med. (2000) 343: 78-85.

[12] Willett WC. Balancing lifestyle and genomics research for disease prevention. Science (2002) 296 (5568): 695-8.

[13] Legoff L, D’Cruz SC, Tevosian S, Primig M, Smagulova F. Transgenerational inheritance of environmentally induced epigenetic alterations during mammalian development. Cells. (2019) 8 (12): 1559.

[14] Waddington CH. Epigenetics and Evolution. Symp. Soc. Exp. Biol. (1953) 7: 186-199.

[15] Deans C, Maggert KA. What do you mean, "epigenetic"? Genetics (2015) 199: 887-896.

[16] Bachman M, Uribe-Lewis S, Yang X, Burgess HE, Iurlaro M, Reik W, Murrell A, Balasubramanian S. 25-Formylcytosine can be a stable DNA modification in mammals. Nature Chemical Biology (2015) 11: 555-557.

[17] $\mathrm{Wu} \mathrm{X}$, Zhang Y. TET-mediated active DNA demethylation: Mechanism, function and beyond. Nature Reviews Genetics (2017) 18: 517-534.

[18] Kitsera N., Allgayer J., Parsa E., Geier N., Rossa M., Carell T., Khobta A. Functional impacts of 5-hydroxymethylcytosine, 5formylcytosine, and 5-carboxycytosine at a single hemimodified $\mathrm{CpG}$ dinucleotide in a gene promoter. Nucleic Acids Res (2017) 45: 11033-11042.

[19] Gimbrone MA, García-Cardeña G. Endothelial cell dysfunction and the pathobiology of atherosclerosis. Circ. Res. (2016) 118: 620-636.

[20] $\mathrm{Hu} \mathrm{Y,} \mathrm{Bajorath} \mathrm{J.} \mathrm{Monitoring} \mathrm{drug} \mathrm{promiscuity} \mathrm{over} \mathrm{time.}$ F1000Research (2014) 3: 218 . doi: 10.12688/f1000research.5250.2.

[21] Melchiorre C, Andrisano V, Bolognesi ML, Budriesi R, Cavalli A, Cavrini V, Rosini M, Tumiatti V, Recanatini M. Acetylcholinesterase noncovalent inhibitors based on a polyamine backbone for potential use against Alzheimer's disease. J Med Chem (1998) 41: 4186-4189.

[22] Merino A, Bronowska AK, Jackson DB, Cahill DJ. Drug profiling: knowing where it hits. Drug Discov. Today (2010) 15 (17-18): 749-756.

[23] Anighoro, A., Bajorath, J, Rastelli, G. Polypharmacology: Challenges and Opportunities in Drug Discovery. J Med Chem (2014) 57: 7874-7887.

[24] Danhof M, Klein K, Stolk P, Aitken M, Leufkens H. The future of drug development: the paradigm shifts towards systems therapeutics, Drug Discovery Today (2018) 23 (12): 1990-1995.

[25] Birtwistle MR, Hansen J, Gallo JM, Sreeharish Muppirisetty S, Ung PM, Iyengar R, Schlessinger A. Systems Pharmacology: An Overview. In: Mager D., Kimko H. (eds) Systems Pharmacology and Pharmacodynamics. AAPS Advances in the Pharmaceutical Sciences Series. 23, Springer, Cham (2016). https://doi.org/10.1007/978-3-319-44534-24.

[26] Yensen J, Naylor S. The Complementary Iceberg Tips of Diabetes and Precision Medicine. J. Precision Med (2016) 3: 39-57. 
[27] Christensen, CM, Grossman MD, Hwang J. The Innovator's Prescription: A Disruptive Solution for Health Care. McGrawHill, New York, NY, USA (2009).

[28] Yau T. "Precision treatment in colorectal cancer: Now and the future". JGH Open (2019) 3 (5): 361-369.

[29] Lu YF, Goldstein DB, Angrist M, Cavalleri G. "Personalized medicine and human genetic diversity". Cold Spring Harbor Perspectives in Medicine (2014) 4 (9): a008581. doi: 10.1101/cshperspect. a008581.

[30] Jones DT, Banito A, Grünewald TG, Haber M, Jäger N, Kool M, Milde T, Molenaar JJ, Nabbi A, Pugh TJ, Schleiermacher G, Smith MA, Frank Westermann F, Pfister SM. "Molecular characteristics and therapeutic vulnerabilities across paediatric solid tumours". Nature Reviews Cancer (2019) 19 (8): 420 438 .

[31] Dowling HF. Present status of therapy with combinations of antibiotics. American Journal of Medicine1 (1965) 39 (5): 796-803.

[32] English AR, Mcbride TJ, Van Halsema G, Caklozzi M. Biologic Studies on PA 775, a Combination of Tetracycline and Oleandomycin with Synergistic Activity. Antibiotics Chemotherapy (1956) 6 (8): 511-22.

[33] Morton Mintz M. FDA and Panalba: A Conflict of Commercial, Therapeutic Goals? Science (1969) 165 (3896): 875-881.

[34] Peltzman S. An Evaluation of Consumer Protection Legislation: The 1962 Drug Amendments. J Political Economy (1973) 81 (5): 1051.

[35] Torok E, Moran E, Cooke F. Oxford Handbook of Infectious Diseases and Microbiology. Oxford University Press (2009) 56. ISBN 9780191039621.

[36] Böhni E. "Chemotherapeutic activity of the combination of trimethoprim and sulfamethoxazole in infections of mice". Postgrad Med J (1969) 45 Suppl: 18-21.

[37] Chou TC. Theoretical basis, experimental design, and computerized simulation of synergism and antagonism in drug combination studies. Pharmacol Rev (2006) 58: 62181 .

[38] Zimmermann GR, Lehar J, Keith CT. Multi-target therapeutics: when the whole is greater than the sum of the parts. DrugDiscov Today (2007) 12: 34-4.

[39] Oberleithner H. Vascular endothelium leaves fingerprints on the surface of erythrocytes. Pflugers Arch (2013) 465 (10): 1451-8.

[40] Halcox JPJ. Endothelial Dysfunction, Editor (s): David Robertson, Italo Biaggioni, Geoffrey Burnstock, Phillip A. Low, Julian F. R. Paton, Primer on the Autonomic Nervous System (Third Edition), Academic Press (2012) 319-324.

[41] Yaroustovsky M, Abramyan M, Krotenko N, Popov D, Plyushch M, Rogalskaya E. A pilot study of selective lipopolysaccharide adsorption and coupled plasma filtration and adsorption in adult patients with severe sepsis. Blood Purif (2015) 39 (1-3): 210-7.

[42] Lang F. Stiff Endothelial Cell Syndrome in Vascular Inflammation and Mineralocorticoid Excess. Hypertension (2011) 57: 146-147.
[43] Oberleithner H, Wälte M, Kusche-Vihrog K. Sodium renders endothelial cells sticky for red blood cells. Front Physiol (2015) 6: 188. https://doi.org/10.3389/fphys.2015.00188.

[44] Goldberg IJ. Lipoprotein lipase and lipolysis: Central roles in lipoprotein metabolism and atherogenesis. J Lipid Res (1996) 37: 693-707.

[45] Uchimido R, Schmidt EP, Shapiro NI. The glycocalyx: a novel diagnostic and therapeutic target in sepsis. Crit Care (2019) 23 (1): 16. doi: 10.1186/s13054-018-2292-6.

[46] Cancel LM, Ebong EE, Mensah S, Hirschberg C, Tarbell JM. Endothelial glycocalyx, apoptosis and inflammation in an atherosclerotic mouse model. Atherosclerosis (2016) 252: 136-146.

[47] Tarbell JM, Pahakis MY. Mechanotransduction and the glycocalyx. J Intern Med (2006) 259 (4): 339-50.

[48] Bertram A, Stahl K, Hegermann J, Haller H. The glycocalyx layer. In R. Hahn (Ed.), Clinical Fluid Therapy in the Perioperative Setting (2016) 73-81. Cambridge: Cambridge University Press.

[49] Zhao RZ, Jiang S, Zhang L, Yu ZB. Mitochondrial electron transport chain, ROS generation and uncoupling (Review). Int J Mol Med (2019) 44: 3-15.

[50] Schieber M, Chandel NS. ROS Function in Redox Signaling and Oxidative Stress. Curr Biol (2014) 9; 24 (10): R453-R462.

[51] Robertson AP. Chronic oxidative stress as a central mechanism for glucose toxicity in pancreatic islet beta cells in diabetes," J. Biol. Chem (2004) 279 (41): 42351-42354.

[52] Brookheart RT, Michel CI, Listenberger LL, D. Ory DS, Schaffer JE. The non-coding RNA gadd7 is a regulator of lipid-induced oxidative and endoplasmic reticulum stress," J. Biol. Chem (2009) 284 (12): 7446-7454.

[53] Rajagopalan S, Al-Kindi SG, Brook RD. Air Pollution and Cardiovascular Disease: JACC State-of-the-Art Review. J Am Coll Cardiol (2018) 23: 72 (17): 2054-2070.

[54] McMurray F, Patten DA, Harper ME. Reactive Oxygen Species and Oxidative Stress in Obesity-Recent Findings and Empirical Approaches. Obesity (Silver Spring) (2016) 24 (11): 2301-2310.

[55] Pizzino G, Irrera $\mathrm{N}$, Cucinotta $\mathrm{M}$, Pallio $\mathrm{G}$, Mannino $\mathrm{F}$, Arcoraci V, Squadrito F, Altavilla D, Bitto A. Oxidative Stress: Harms and Benefits for Human Health. Oxid Med Cell Longevity. Article ID (2017) 8416763. https://oi.org/10.1155/2017/84167631.

[56] Zeliger HI. Causes, Mechanisms and Prevention of Environmental Diseases. Dual Diagn Open Acc (2015) 1: 1. doi: $10.21767 / 2472-5048.100001$.

[57] Cohen AJ, Brauer M, Burnett R, Anderson HR, Frostad J, Estep K, Balakrishnan K, Brunekreef B, Dandona L, Dandona R, Feigin V, Freedman G, Hubbell B, Jobling A, Kan H, Knibbs L, Liu Y, Martin R, Morawska L, Pope CA 3rd, Shin H, Straif K, Shaddick G, Thomas M, van Dingenen R, van Donkelaar A, Vos T, Murray CJL, Forouzanfar MH. Estimates and 25-year trends of the global burden of disease attributable to ambient air pollution: an analysis of data from the Global Burden of Diseases Study Lancet (2017) 13; 389 (10082): 1907-1918. 
[58] Thangam EB, Jemima EA, Singh H, Baig MS, Khan M, Mathias CB, Church MK, Saluja R. The Role of Histamine and Histamine Receptors in Mast Cell-Mediated Allergy and Inflammation: The Hunt for New Therapeutic Targets. Front Immunol (2018) 13; 9: 1873. doi: 10.3389/fimmu.2018.01873.

[59] Benly P. Role of Histamine in Acute Inflammation J. Pharm. Sci. \& Res (2015) 7 (6): 373-376.

[60] Fulda F, Gorman AM, Hori O, Samali A. Cellular Stress Responses: Cell Survival and Cell Death. Inter. J. Cell Biol. Article ID (2010) 214074. https://doi.org/10.1155/2010/214074.

[61] Xu L, Cheng D, Huang Z, Ding S, Zhang W, Tan H, Shi H, Chen R, Zou Y, Wang TC, Yang X, Ge J. Histamine promotes the differentiation of macrophages from $\mathrm{CD} 11 \mathrm{~b}+$ myeloid cells and formation of foam cells through a Stat6-dependent pathway. Atherosclerosis (2017) 263: 42-52.

[62] McFarlane SI (ed). Dyslipidemia. IntechOpen (2019) DOI: 10.5772/intechopen.76825.

[63] Brown MS, Goldstein JL. Familial hypercholesterolemia: defective binding of lipoproteins to cultured fibroblasts associated with impaired regulation of 3-hydroxy-3methylglutaryl coenzyme A reductase activity. Proc Natl Acad Sci U S A (1974) 71 (3): 788-92.

[64] Sigurdsson G, Nicoll A, Lewis B. Conversion of very lowdensity lipoprotein to low density lipoprotein. A metabolic study of apolipoprotein B kinetics in human subjects J Clin Invest (1976) 56 (6): 1481-90.

[65] Le Goff W, Guerin M, Chapman MJ. Pharmacological modulation of cholesterol ester transfer protein, a new therapeutic target in atherogenic dyslipidemia. Pharmacol Ther (2004) 101: 17-38.

[66] Nettleton JA, Brouwer IA, Geleijnse JM, Hornstra G. Saturated Fat Consumption and Risk of Coronary Heart Disease and Ischemic Stroke: A Science Update. Ann. Nut. Metab (2017) 70 (1): 26-33.

[67] Prenner SB, Mulvey CK, Ferguson JF, Rickels MR, Bhatt AB, Reilly MP. Very low-density lipoprotein cholesterol associates with coronary artery calcification in type 2 diabetes beyond circulating levels of triglycerides Atherosclerosis (2014) 236 (2): 244-250.

[68] Nordestgaard BG. Triglyceride-rich lipoproteins and atherosclerotic cardiovascular disease: new insights from epidemiology, genetics, and biology. Circ Res (2016) 118: 547-563.

[69] Praagman J, de Jonge EA, Kiefte-de Jong JC, Beulens JW, Sluijs I, Schoufour JD, Hofman A, van der Schouw YT, Franco OH. Dietary Saturated Fatty Acids and Coronary Heart Disease Risk in a Dutch Middle-Aged and Elderly Population. Arterioscler Thromb Vasc Biol (2016) 36 (9): 2011-8.

[70] Hozumi T, Eisenberg M, Sugioka K, Kokkirala AR, Watanabe $\mathrm{H}$, Teragaki M, Yoshikawa J, Homma S. Change in coronary flow reserve on transthoracic Doppler echocardiography after a single high-fat meal in young healthy men. Ann Intern Med (2002) 136 (7): 523-8.

[71] Hikmat F, Appel LJ. Effects of the DASH diet on blood pressure in patients with and without metabolic syndrome: Results from the DASH trial. J Human Hypertension (2014) 28: 170-175.

[72] Widmer RJ, Flammer AJ, Lerman LO, and Lerman A. "The
Mediterranean Diet, its Components, and Cardiovascular Disease. Am J Med (2015) 128 (3): 229-238.

[73] Paul AA, Southgate DAT. McCance and Widdowson's The Composition of Foods, Fourth revised and extended edition of MRC Special Report No 297 (1985) London Amsterdam Her Majesty's Stationery Office Elsevier North Holland Biomedical Press.

[74] Liu H, Pathak P, Boehme S, Chiang JY. Cholesterol $7 \alpha-$ hydroxylase protects the liver from inflammation and fibrosis by maintaining cholesterol homeostasis. J Lipid Res (2016) 57 (10) 1831-1844.

[75] Lecerf JM, de Lorgeril M. "Dietary cholesterol: from physiology to cardiovascular risk". The British Journal of Nutrition (2011) 106 (1): 6-14.

[76] Soliman GA. Dietary Cholesterol and the Lack of Evidence in Cardiovascular Disease. Nutrients (2018) 10 (6): 780. doi: 10.3390/nu10060780.

[77] Gibson CM, Diaz L, Kandarpa K, Sacks FM, Pasternak RC, Sandor T, Feldman C, Stone PH. Relation of vessel wall shear stress to atherosclerosis progression in human coronary arteries. Arterioscler Thromb (1993) 13 (2): 310-5.

[78] VanderLaan PA, Reardon CA, Getz GS. Site specificity of atherosclerosis: site-selective responses to atherosclerotic modulators. Arterioscler Thromb Vasc Biol (2004) 24 (1): 1222.

[79] Chiu JJ, Chien S. Effects of disturbed flow on vascular endothelium: pathophysiological basis and clinical perspectives. Physiol Rev (2011) 91 (1): 327-87.

[80] Giddens DP, Zarins CK, Glagov S. The Role of Fluid Mechanics in the Localization and Detection of Atherosclerosis. J Biomech Eng (1993) 115 (4B): 588-594.

[81] Slager C, Wentzel J. The Role of Shear Stress in the Generation of Rupture-Prone Vulnerable Plaques, Nat. Clin. Pract. Cardiovasc. Med (2005) 2: 401-407.

[82] Mills NL, Donaldson K, Hadoke PW, Boon NA, MacNee W, Cassee FR, Sandstrom T, Blomberg A, Newby DE. Adverse cardiovascular effects of air pollution. Nat Clin Pract Cardiovasc Med (2009) 6: 36-44.

[83] Hansson GK, Libby P, Tabas I. Inflammation, and plaque vulnerability. J Intern Med (2015) 278 (5): 483-93.

[84] Mozaffarian D, Benjamin EJ, Go AS, Arnett DK, Blaha MJ, Cushman M, de Ferranti S, Després JP, Fullerton HJ, Howard VJ, Huffman MD, Judd SE, Kissela BM, Lackland DT, Lichtman JH, Lisabeth LD, Liu S, Mackey RH, Matchar DB, McGuire DK, Mohler ER, Moy CS, Muntner P, Mussolino ME, Nasir K, Neumar RW, Nichol G, Palaniappan L, Pandey DK, Reeves MJ, Rodriguez CJ, Sorlie PD, Stein J, Towfighi A, Turan TN, Virani SS, Willey JZ, Woo D, Yeh RW, Turner MB. Heart disease and stroke statistics--2015 update: a report from the American Heart Association. Circulation (2015) 131 (4): e29-3221.

[85] Solinas C, Saba L, Sganzerla P, Petrelli F. Venous and arterial thromboembolic events with immune checkpoint inhibitors: A systematic review. Thrombosis Research (2020) 196: 444-453.

[86] Kent KC. "Clinical practice. Abdominal aortic aneurysms". New England J Med (2014) 371 (22): 2101-8. 
[87] Wendelboe AM, Raskob GE. Global Burden of Thrombosis Epidemiologic Aspects. Circulation Research (2016) 118: $1340-1347$.

[88] Song P, Rudan D, Zhu Y, Fowkes FJ, Rahimi K, Fowkes FG, Rudan I. Global, regional, and national prevalence and risk factors for peripheral artery disease in 2015: an updated systematic review and analysis. Lancet Glob Health (2019) 7: e1020-30.

[89] Malas MB, Naazie IN, Elsayed N, Mathlouthi A, Marmor R, Clary B. Thromboembolism risk of COVID-19 is high and associated with a higher risk of mortality: A systematic review and meta-analysis. EClinicalMedicine (2020) 29-30.

[90] Anitschkow N. Uber die veranderungen der kaninchenaorta bei experimenteller cholesterinsteatose. Beitr Pathol Anat (1913) 56: 379-404.

[91] Bortx WM. Reversibility of Atherosclerosis in CholesterolFed Rabbits. Circulation Res (1968) 22: 135-139.

[92] Wissler RW, Vesselinovitch D. Studies of regression of advanced atherosclerosis in experimental animals and man. Ann N Y Acad Sci (1976) 275: 363-378.

[93] Keys A (ed). Coronary heart disease in seven countries. Circulation (1970) 41 (4S1): 1-198.

[94] Liu SK, Tilley LP, Tappe JP, Fox PR. Clinical and pathologic findings in dogs with atherosclerosis: 21 cases (1970-1983). J Am Vet Med Assoc (1986) 189: 227-32.

[95] Barrie J, Watson TDG, Stear MJ, Nash AS. Plasma cholesterol and lipoprotein concentrations in the dog: the effects of age, breed, gender, and endocrine disease. J Small Anim Pract (1993) 34: 507-12.

[96] Cave, NJ, Allan, FJ, Schokkenbroek SL, Metekohy CA, Pfeiffer DU. A cross-sectional study to compare changes in the prevalence and risk factors for feline obesity between 1993 and 2007 in New Zealand. Prev. Vet. Med (2012) 107: 121133.

[97] Kienzle E. Blood sugar levels and renal sugar excretion after the intake of high carbohydrate diets in cats. J. Nutrition (2004) 124: 2563S-2567S.

[98] Ishibashi S, Brown MS, Goldstein JL, Gerard RD, Hammer RE, Herz J. Hypercholesterolemia in low density lipoprotein receptor knockout mice and its reversal by adenovirusmediated gene delivery. J Clin Invest (1993) 92 (2): 883-93.

[99] Plump AS, Smith JD, Hayek T, Aalto-Setälä K, Walsh A, Verstuyft JG, Rubin EM, Breslow JL. Severe hypercholesterolemia and atherosclerosis in apolipoprotein Edeficient mice created by homologous recombination in ES cells. Cell (1992) 71 (2): 343-53, 1992.

[100] Zhang SH, Reddick RL, Piedrahita JA, Maeda N. Spontaneous hypercholesterolemia and arterial lesions in mice lacking apolipoprotein E. Science (1992) 258 (5081): 468-71.

[101] Libby P, Ridker P, Hansson G. Progress, and challenges in translating the biology of atherosclerosis. Nature (2011) 473: 317-325.

[102] Krauss RM. Lipoprotein subfractions and cardiovascular disease risk. Curr Opin Lipidol (2010) 21 (4): 305-11.

[103] Schwartz SM, Galis Z, Rosenfeld ME, Falk E. Plaque rupture in humans and mice. Arterioscler Thromb Vasc Biol (2007)

\section{7: 705-713.}

[104] Wang Y, Johnson JA, Fulp A, Sutton MA, Lessner SM. Adhesive strength of atherosclerotic plaque in a mouse model depends on local collagen content and elastin fragmentation. J. Biomech (2013) 46 (4): 716-22.

[105] Rosenfeld ME, Averill MM, Bennett BJ, Schwartz SM. Progression, and disruption of advanced atherosclerotic plaques in murine models. Curr Drug Targets (2008) 9 (3): 210-6.

[106] Adams LD, Geary RL, Li J, Rossini A, Schwartz SM. Expression profiling identifies smooth muscle cell diversity within human intima and plaque fibrous cap: loss of RGS5 distinguishes the cap. Arterioscler Thromb Vasc Biol (2006) 26: 319-325.

[107] Cheruvu PK, Finn AV, Gardner C, Caplan J, Goldstein J, Stone GW, Virmani R, Muller JE. Frequency and distribution of thin cap fibroatheroma and ruptured plaques in human coronary arteries: a pathologic study. J Am Coll Cardiol (2007) 4: 50 (10): 940-9.

[108] Gore I, Tejada C. The Quantitative Appraisal of Atherosclerosis. Am J Pathol (1957) 33 (5): 875-885.

[109] World Health Organization Study Group. Classification of atherosclerotic lesions: report of a study group. WHO Tech Rep Ser (1958) 143: 1-20.

[110] Stary HC, Chandler AB, Dinsmore RE, Fuster V, Glagov S, Insull W, Rosenfeld ME, Schwartz CJ, Wagner WD, Wissler RW. A Definition of Advanced Types of Atherosclerotic Lesions and a Histological Classification of Atherosclerosis: A Report from the Committee on Vascular Lesions of the Council on Arteriosclerosis, American Heart Association. Circulation (1995) 92: 1355-1374.

[111] Stary HC, Blankenhorn DH, Chandler AB, Glagov S, Insull W Jr, Richardson M, Rosenfeld ME, Schaffer SA, Schwartz CJ, Wagner WD. A definition of the intima of human arteries and of its atherosclerosis-prone regions. A report from the Committee on Vascular Lesions of the Council on Arteriosclerosis, American Heart Association. Arterioscler Thromb (1992) 12 (1): 120-34.

[112] Stary HC, Chandler AB, Glagov S, Guyton JR, Insull W Jr, Rosenfeld ME, Schaffer A, Schwartz CJ, Wagner WD, Wissler RW. A definition of initial, fatty streak, and intermediate lesions of atherosclerosis. Arterioscler Thromb (1994) 14: 840-856.

[113] Stary HC. Macrophages, macrophage foam cells, and eccentric intimal thickening in the coronary arteries of young children. Atherosclerosis (1987) 64: 91-108.

[114] Gerrity RG. The role of the monocyte in atherogenesis: II. Migration of foam cells from atherosclerotic lesions. Am J Pathol (1981) 103 (2): 191-200.

[115] Lewis JC, Taylor RG, Jerome WG. Foam cell characteristics in coronary arteries and aortas of White Carneau pigeons with moderate hypercholesterolemia. Ann N Y Acad Sci (1985) 454: 91-100.

[116] Rosenfeld ME, Tsukada T, Gown AM, Ross R. Fatty streak initiation in Watanabe Heritable Hyperlipemic and comparably hypercholesterolemic fat-fed rabbits. Arteriosclerosis (1987) 7: 9-23. 
[117] Faggioto A, Ross R, Harker L. Studies of hypercholesterolemia in the nonhuman primate, I: changes that lead to fatty streak formation. Arteriosclerosis (1984) 4: 323-340.

[118] Uemura K, Sternby N, Vanecek R, Vihert A, Kagan A. Grading atherosclerosis in aorta and coronary arteries obtained at autopsy application of a tested method. Bull World Health Organ (1964) 31 (3): 297-320.

[119] Constantinides P. Production of experimental atherosclerosis in animals. J. Atheroscler Res (1961) 1: 374-385.

[120] Michael E. Rosenfeld ME, Polinsky P, Virmani R, Kauser K, Rubanyi G, Schwartz SM. Advanced Atherosclerotic Lesions in the Innominate Artery of the ApoE Knockout Mouse. Arterioscler Thromb Vasc Biol (2000) 20: 2587-2592.

[121] Van Herck JL, De Meyer GRY, Martinet W, Van Hove CE, Foubert K, Theunis MH, Apers S, Bult H, Vrints CJ, Herman AG. Impaired Fibrillin-1 Function Promotes Features of Plaque Instability in Apolipoprotein E-Deficient Mice. Circulation (2009) 120: 2478-2487.

[122] Biomarkers Definitions Working Group. Biomarkers and surrogate endpoints: preferred definitions and conceptual framework. Clin Pharmacol Ther (2001) 69: 89-95.

[123] Parsanathan R, Jain SK. (. Metabolic Syndrome and Related Disorders. Mary Ann Liebert's publishers (2020) 18 (1): 1030.

[124] Kok WE. Biomarker panels for prognosis prediction in heart failure on a CHARM basis. J Lab Precis Med (2017) 2: 25-28.

[125] Wooley P, Tunac J. A novel model of atherosclerosis in mice. Joint Conference on 17th European Heart Disease and Heart Failure Congress and 2nd International Conference on Cardiovascular Medicine and Cardiac Surgery (2017) London, UK. (Scientific Tracks Abstracts).

[126] Seidel C, Sundan A, Hjorth M, Turesson I, Dahl IMS, Abildgaard N, Waage A, Børset M. Serum syndecan-1: a new independent prognostic marker in multiple myeloma. Blood (2000) 95 (2): 388-392.

[127] Joensuu H, Anttonen A, Eriksson M, Mäkitaro R, Alfthan H, Kinnula V, Leppä S. Soluble Syndecan-1 and Serum Basic Fibroblast Growth Factor Are New Prognostic Factors in Lung Cancer. Cancer Res (2002) 62: 5210-5217.

[128] Bielecka-Dabrowa A, Michalska-Kasiczak M, Gluba A, Ahmed A, Gerdts E, von Haehling S, Rysz J, Banach M. Biomarkers and Echocardiographic Predictors of Myocardial Dysfunction in Patients with Hypertension. Sci Rep (2015) 5, 8916. https://doi.org/10.1038/srep08916.

[129] Yablecovitch D, Stein A, Shabat-Simon M, Naftali T, Gabay G, Laish I, Oren A, Konikoff FM. Soluble Syndecan-1 Levels Are Elevated in Patients with Inflammatory Bowel Disease. Dig Dis Sci (2015) 60: 2419-2426.

[130] de Oliveira Neves FM, Meneses GC, Sousa NEA, Menezes RR, Parahyba MC, Martins AMC, Libório AB. Syndecan-1 in Acute Decompensated Heart Failure - Association with Renal Function and Mortality. Circulation (2015) 79 (7): 1511-1519.

[131] Takahashi R, Negishi K, Watanabe A, Arai M, Naganuma F, Ohyama Y, Kurabayashi M, Serum syndecan-4 is a novel biomarker for patients with chronic heart failure, J Cardiol (2011) 57 (11): 325-332
[132] Miranda CH, de Carvalho Borges M, Schmidt A, Marin-Neto JA, Pazin-Filho A. Evaluation of the endothelial glycocalyx damage in patients with acute coronary syndrome. Atherosclerosis (2016) 247: 184-188.

[133] Rehm M, Bruegger D, Christ, Conzen P, Thiel M, Jacob M, Chappell D, Stoeckelhuber M, Welsch U, Reichart B, Peter K, Becker BF. Shedding of the Endothelial Glycocalyx in Patients Undergoing Major Vascular Surgery with Global and Regional Ischemia Circulation (2007) 116: 1896-1906.

[134] Gandley RE, Althouse A, Jeyabalan A, Bregand-White JM, McGonigal S, Myerski AC, Gallaher M, Powers RW, Hubel CA. Low Soluble Syndecan-1 Precedes Preeclampsia. PLOS One (2016) https://doi.org/10.1371/journal.pone.0157608.

[135] Vlahu CA, Lemkes BA, Struijk DG, Koopman MG, Krediet RT, Vink H. Damage of the Endothelial Glycocalyx in Dialysis Patients. J Am Soc Nephrology (2012) 23 (11): 19001908.

[136] Rehm M, Bruegger D, Christ F, Conzen P, Thiel M, Jacob M, Chappell D, Stoeckelhuber M, Welsch U, Reichart B, Peter K, Becker BF. Shedding of the Endothelial Glycocalyx in Patients Undergoing Major Vascular Surgery with Global and Regional Ischemia. Circulation (2007) 116: 1896-1906.

[137] Haywood-Watson RJ, Holcomb JB, Gonzalez EA, Peng Z, Pati S, Park PW, Wang WW, Zaske AM, Menge T, Kozar RA. Modulation of Syndecan-1 Shedding after Hemorrhagic Shock and Resuscitation. PLOS One (2011) https://doi.org/10.1371/journal.pone.0023530.

[138] Tang TH, Alonso S, Ng LF, Thein TL, Pang VJ, Leo YS, Lye DC, Yeo TW. Increased Serum Hyaluronic Acid and Heparan Sulfate in Dengue Fever: Association with Plasma Leakage and Disease Severity. Scientific Reports (2017) 7: 46191 DOI: 10.1038/srep46191.

[139] Nemme J, Hahn RG, Krizhanovskii C, Ntika S, Sabelnikovs O, Vanags I. Minimal shedding of the glycocalyx layer during abdominal hysterectomy. BMC Anesthesiol (2017) 17 (1): 107. doi: 10.1186/s12871-017-0391-6.

[140] Tomatsui S, Gutierrez MA, Ishimaru T, Pena OM, Montano AM, Maeda H, Velez-Castrilloni S, Nishioka T, Fachel AA, Cooper A, Thornley M, Wraith E, Barrera A, Laybauer LS, Giuglani R, Schwartz IV, Schulze G, Beck M, Kircher SG, Paschke E, Yamaguchi S, Ullrich K, Isogai K, Suzuki Y, Orii T, Noguchi. Heparan sulfate levels in mucopolysaccharidoses and mucolipidoses. J. Inherit. Metab. Dis (2005) 28: 743-757.

[141] Khedun SM, Naicker T, Moodley J, Gathiram P. Urinary heparan sulfate proteoglycan excretion in black African women with pre-eclampsia. Acta Obstet Gynecol Scand (2002) 81 (4): 308-12.

[142] Majeed M, McQueen F, Yeoman S, McLean L. Relationship between serum hyaluronic acid level and disease activity in early rheumatoid arthritis. Ann Rheum Dis (2004) 63 (9): 1166-8.

[143] Gudowska M, Gruszewska E, Panasiuk A, Cylwik B, Flisiak R, Świderska M, Szmitkowski M, Chrostek L. Hyaluronic acid concentration in liver diseases. Clin Exp Med (2016) 16 (4): 523-528.

[144] Plevris JN, Haydon GH, Simpson KJ, Dawkes R, Ludlum CA, Harrison DJ, Hayes PC. Serum hyaluronan--a non-invasive test for diagnosing liver cirrhosis. Eur J Gastroenterol Hepatol (2000) 12 (10): 1121-7. 
[145] Tangkijvanich P, Kongtawelert P, Pothacharoen P, Mahachai V, Suwangool P, Poovorawan Y. Serum hyaluronan: a marker of liver fibrosis in patients with chronic liver disease. Asian Pac J Allergy Immunol (2003) 21 (2): 115-20.

[146] Halfon P, Bourlière M, Pénaranda G, Deydier R, Renou C, Botta-Fridlund D, Tran A, Portal I, Allemand I, RosenthalAllieri A, Ouzan D. Accuracy of hyaluronic acid level for predicting liver fibrosis stages in patients with hepatitis $\mathrm{C}$ virus. Comp Hepatol (2000) 11; 4: 6. doi: 10.1186/1476-59264-6.

[147] Fujimoto N, Gemba K, Asano M, Fuchimoto Y, Wada S, Ono K, Ozaki S, Kishimoto T. Hyaluronic acid in the pleural fluid of patients with malignant pleural mesothelioma. Respir Investig (2013) 51 (2): 92-7.

[148] Raimondi F, Ferrara T, Maffucci R, Milite P, Del Buono D, Santoro P, Capasso L, Grimaldi E. Neonatal sepsis: a difficult diagnostic challenge. Clin Biochem (2011) 44 (7): 463-464.

[149] Jhan, MK., Tsai, TT., Chen, CL. Tsai CC, Cheng YL, Lee YC, Ko CY, Lin YS, Chang CP, Lin LT, Lin CF. Dengue virus infection increases microglial cell migration. Sci Rep (2017) 7, 91. https://doi.org/10.1038/s41598-017-00182-z.

[150] Haapaniemi E, Tatlisumak T, Soinne L, Syrjälä M, Kaste M. Plasminogen activator inhibitor-1 in patients with ischemic stroke. Acta Neurochir Suppl (2000) 76: 277-8.

[151] Kim SH, Han SW, Kim EH, Kim DJ, Lee KY, Kim D, Heo JH. Plasma Fibrinolysis Inhibitor Levels in Acute Stroke Patients with Thrombolysis Failure. J Clin Neurol (2005) 1 (2): 142-147.

[152] Huber K, Resch I, Stefenelli T, Lang I, Probst P, Kaindl F, Binder BR. Plasminogen activator inhibitor-1 levels in patients with chronic angina pectoris with or without angiographic evidence of coronary sclerosis. Thrombosis and Haemostasis (1990) 63 (3): 336-339.

[153] Islam S, Yakout SM, Daghri NM, Alhomida AS, Khan HA. Serum levels of thrombotic markers in patients with acute myocardial infarction. Int J Clin Exp Med (2014) 7 (4): 10591063.

[154] Gyöngyösi M, Glogar D, Weidinger F, Domanovits $H$, Laggner A, Wojta J, Zorn G, Iordanova N, Huber K. Association between plasmin activation system and intravascular ultrasound signs of plaque instability in patients with unstable angina and non-st-segment elevation myocardial infarction. Am Heart J (2004) 147 (1): 158-64.

[155] Daví G, Violi F, Catalano I, Giammarresi C, Putignano E, Nicolosi G, Barbagallo M, Notarbartolo A. Increased plasminogen activator inhibitor antigen levels in diabetic patients with stable angina. Blood Coagul Fibrinolysis (1991) $2(1): 41-5$.

[156] Habib SS, Gader AGM, Kurdi MI, Suriya MO, Aseri ZA. Tissue plasminogen activator and plasminogen activator inhibitor-1 levels in patients with acute myocardial infarction and unstable angina. J Pak Med Assoc (2012) 62 (7): 681-684.

[157] Nadarajah Srikumar, Nancy J. Brown, Paul N. Hopkins, Xavier Jeunemaitre, Steven C. Hunt, Douglas E. Vaughan, Gordon H. Williams, PAI-1 in human hypertension: relation to hypertensive groups, American Journal of Hypertension (2002) 15 (8): 683-690.

[158] Forood A, Malekpour-Afshar R, Mahdavi A. Serum level of plasminogen activator inhibitor type-1 in addicted patients with coronary artery disease. Addiction \& Health. SummerAutumn (2014) 6 (3-4): 119-126.

[159] Knudsen EC, Seljeflot I, Abdelnoor M, Eritsland J, Mangschau A, Muller C, Arnesen H, Andersen GO. Elevated levels of PAI-1 activity and t-PA antigen are associated with newly diagnosed abnormal glucose regulation in patients with ST-elevation myocardial infarction. J Thromb Haemost (2011) 9 (8): 1468-74. (164) (166) Iwadate Y, Hayama M, Adaxchi A, Matsutani T, Nagai Y, Hiwasa T, Saeki N. High Serum Level of Plasminogen Activator Inhibitor-1 Predicts Histological Grade of Intracerebral Gliomas. Anticancer Res (2008) 28: 415-418.

[160] Iwadate Y, Hayama M, Adaxchi A, Matsutani T, Nagai Y, Hiwasa T, Saeki N. High Serum Level of Plasminogen Activator Inhibitor-1 Predicts Histological Grade of Intracerebral Gliomas. Anticancer Res (2008) 28: 415-418.

[161] Thögersen AM, Jansson JH, Boman K, Nilsson TK, Weinehall L, Huhtasaari F, Hallmans G. High Plasminogen Activator Inhibitor and Tissue Plasminogen Activator Levels in Plasma Precede a First Acute Myocardial Infarction in Both Men and Women Evidence for the Fibrinolytic System as an Independent Primary Risk Factor. Circulation (1998) 98: 2241-2247.

[162] Cao RN, Tang L, Xia ZY, Xia R. Endothelial glycocalyx as a potential therapeutic target in organ injuries. Chin Med J (Engl) (2019) 132 (8): 963-975.

[163] Leonhard Möckl, Kayvon Pedram, Anish R. Roy, Venkatesh Krishnan, Anna-Karin Gustavsson, Oliver Dorigo, Carolyn R. Bertozzi, W. E. Moerner. Quantitative Super-Resolution Quantitative Super-Resolution Microscopy of the Mammalian Glycocalyx, Developmental Cell (2019) 50 (1): 57-72.

[164] Milbrath MO, Wenger Y, Chang CW, Emond C, Garabrant D, Gillespie BW, Jolliet O. Apparent half-lives of dioxins, furans, and polychlorinated biphenyls as a function of age, body fat, smoking status, and breast-feeding. Environ Health Perspect (2009) 117 (3): 417-25.

[165] Hue O, Marcotte J, Berrigan F, Simoneau M, Doré J, Marceau P, Marceau S, Tremblay A, Teasdale N. Plasma concentration of organochlorine compounds is associated with age and not obesity. Chemosphere (2007) 67 (7): 1463-1467.

[166] Gottesman MM, Collins FS. The role of the human genome project in disease prevention. Preventive Medicine (1994) 23 (5): 591-594.

[167] Terry C, Lesser N. Unlocking R\&D productivity: Measuring the return from pharmaceutical innovation (2018). London: Deloitte Centre for Health Solutions.

[168] Frank SA, Rosner MR. "Nonheritable cellular variability accelerates the evolutionary processes of cancer," PLoS Biology (2012) 10 (4), Article ID e1001296.

[169] Sun H, Guo Y, Lan X, Jia J, Cai X, Zhang G, Xie J, Liang Q, Li Y, Yu G. PhenoModifier: a genetic modifier database for elucidating the genetic basis of human phenotypic variation. Nucleic Acids Res (2020) 48: D977-D982.

[170] Lichtenstein P, Holm NV, Verkasalo PK, Iliadou A, Kaprio J, Koskenvuo M, Pukkala E, Skytthe A, Hemminki K. Environmental and heritable factors in the causation of cancer--analyses of cohorts of twins from Sweden, Denmark, and Finland. N. Engl. J. Med (2000) 343, 78. 
[171] Muka T, Koromani F, Portilla E, O'Connor A, Bramer WM, Troup J, Chowdhury R, Dehghan A, Franco OH. The role of epigenetic modifications in cardiovascular disease: A systematic review. Int. J. Cardiol (2016) 212: 174-183.

[172] Santos R, Ursu O, Gaulton A, Bento AP, Donadi RS, Bologa CG, Karlsson A, Al-Lazikani B, Hersey A, Oprea TI, Overington JP. A comprehensive map of molecular drug targets. Nat Rev Drug Discov (2017) 16 (1): 19-34.

[173] Rappaport N, Twik M, Plaschkes I, Nudel R, Iny Stein T, Levitt J, Gershoni M, Morrey CP, Safran M, and Lancet D. MalaCards: an amalgamated human disease compendium with diverse clinical and genetic annotation and structured search. Nucleic Acids Res (2017) 45: D877-D887.

[174] Schöneberg T, Schulz A, Biebermann H, Hermsdorf T, Römpler H, Sangkuhl K. Mutant G-protein-coupled receptors as a cause of human diseases. Pharmacology \& Therapeutics (2004) 104 (3): 173-206.

[175] Insel PA, Sriram K, Gorr MW, Wiley SZ, Michkov A, Salmerón C, Chinn AM. GPCRomics: An Approach to Discover GPCR Drug Targets. Trends Pharmacol Sci (2019) 40 (6): 378-387.

[176] Hauser AS, Attwood MM, Rask-Andersen M, Schiöth HB, Gloriam DE. Trends in GPCR drug discovery: new agents, targets, and indications. Nat Rev Drug Discov (2017) 16 (12): 829-842.

[177] Al Aboud NM, Tupper C, Jialal I. Genetics, Epigenetic Mechanism. In: StatPearls Publishing (2020). PMID: 30422591 .

[178] Dogra S, Sona C, Kumar A, Yadav PN. Epigenetic regulation of $\mathrm{G}$ protein coupled receptor signaling and its implications in psychiatric disorders, Int. J. Biochem. Cell Biol (2016) 77 (Part B): 226-239.

[179] Reeskamp LF, Venem A, Pereira JPB, Levin E, Nieuwdorp M, Groen AK, Defesch JC, Grefhorst A, Henneman P, Hovingh GK. Differential DNA methylation in familial hypercholesterolemia. EBioMedicine (2020) 61.103079 .0 https://doi.org/10.1016/j.ebiom.2020.103079.

[180] González-Becerra K, Ramos-Lopez O, Barrón-Cabrera E, Riezu-Boj JI, F. I. Milagro FI, Martínez-López E, Martínez JA Fatty acids, epigenetic mechanisms, and chronic diseases: a systematic review. Lipids Health Dis (2019) 18, 178. https://doi.org/10.1186/s12944-019-1120-6.

[181] Biswas S, Rao CM. Epigenetic tools (The Writers, The Readers and The Erasers) and their implications in cancer therapy. Eur J Pharmacol (2018) 837: 8-24.

[182] Montalvo-Casimiro M, González-Barrios R, MerazRodriguez MA, Juárez-González VT, Arriaga-Canon C, Herrera LA. Epidrug Repurposing: Discovering New Faces of Old Acquaintances in Cancer Therapy. Frontiers $\begin{array}{llll}\text { Oncology } & (2020) & 10: & 2461 .\end{array}$ https://www.frontiersin.org/article/10.3389/fonc.2020.60538 $6)$.

[183] Fior Markets: Epigenetics Drugs \& Diagnostic Technologies Market by Product (Services, Enzymes, Instruments, Kits, Reagents), Technology (Chromatin Structures, Micro RNA Modification, Large Non-Coding RNA, Histone Acetylation, Histone Methylation, DNA Methylation), Region, Global Industry Analysis, Market Size, Share, Growth, Trends, and $\begin{array}{lll}\text { Forecast } & 2020 & \text { to }\end{array}$ https://www.fiormarkets.com/report/epigenetics-drugsdiagnostic-technologies-market-by-product-418825.html.

[184] Sriram K, Insel PA. G Protein-Coupled Receptors as Targets for Approved Drugs: How Many Targets and How Many Drugs? Mol. Pharmacol (2018) 93 (4): 251-258.

[185] Oprea TI, Bologa CG, Brunak S, Campbell A, Gan GN, Gaulton A, Gomez SM, Guha R, Hersey A, Holmes J, Jadhav A, Jensen LJ, Johnson GL, Karlson A, Leach AR, Ma'ayan A, Malovannaya A, Mani S, Mathias SL, McManus MT, Meehan TF, von Mering C, Muthas D, Nguyen DT, Overington JP, Papadatos G, Qin J, Reich C, Roth BL, Schürer SC, Simeonov A, Sklar LA, Southall N, Tomita S, Tudose I, Ursu O, Vidovic D, Waller A, Westergaard D, Yang JJ, Zahoránszky-Köhalmi G. Unexplored therapeutic opportunities in the human genome. Nat Rev Drug Discov (2018) 17 (5): 317-332.

[186] Hopkins Al. Drug discovery: Predicting promiscuity. Nature (2009) 462 (7270): 167-168.

[187] Chinwalla AT, Cook LL, Delehaunty KD, Fewell GA, Fulton LA, Fulton RS, Graves TA, Hillier LW, Mardis ER, McPherson JD, Miner TL, Nash WE, Nelson JO, Nhan MN, Pepin KH, Pohl CS, Ponce TC, Schultz B, Thompson J, Trevaskis E, Waterston RH, Wendl MC, Wilson RK, Yang SP. Initial sequencing, and comparative analysis of the mouse genome. Nature (2002) 420, 520-562.

[188] Paigen B, Mitchell D, Reue K, Morrow A, Lusis AJ, LeBoeuf RC. Ath-1, a gene determining atherosclerosis susceptibility and high-density lipoprotein levels in mice. Proc. Natl. Acad. Sci. USA (1987) 84: 3763-3767.

[189] Getz GS, Reardon CA. Diet and Murine Atherosclerosis. Arterioscler Thromb Vasc Biol (2006) 26: 242-249.

[190] Mente A, de Koning L, Shannon HS, Anand SS. A systematic review of the evidence supporting a causal link between dietary factors and coronary heart disease. Arch Intern Med (2009) 169 (7): 659-69.

[191] Zethelius B, Berglund L, Sundström J, Ingelsson E, Basu S, Larsson A, Venge P, Johan Ärnlöv J. Use of Multiple Biomarkers to Improve the Prediction of Death from Cardiovascular Causes. N Engl J Med (2008) 358: 2107-2116.

[192] Arbab-Zadeh Nakano AM, Virmani R, V. Fuster V. Acute coronary events Circulation (2012) 125: 1147-1156.

[193] Arrey-Mbi TB, Klusewitz SM, Villines TC. Long-Term Prognostic Value of Coronary Computed Tomography Angiography. Curr Treat Options Cardiovasc Med (2017) 12; 19 (12): 90. doi: 10.1007/s11936-017-0588-5.

[194] Budoff MJ, Shaw LL, Liu ST, Weinstein SR, Tseng PH, Flores FR, Callister TQ, Raggi P, Berman DS, Mosler TP. Long-Term Prognosis Associated with Coronary Calcification: Observations from a Registry of 25,253 Patients, J. Am. Coll. Cardiol (2007) 49 (18): 1860-1870.

[195] Arbab-Zadeh A, Fuster V. From Detecting the Vulnerable Plaque to Managing the Vulnerable Patient: JACC State-ofthe-Art Review, J. Am. Coll. Cardiol (2019) 74 (12): 15821593.

[196] Hillegass JM, Murphy KA, Villano CM, White LA. The impact of aryl hydrocarbon receptor signaling on matrix metabolism: Implications for development and disease. Biol Chem (2006) 387 (9): 1159-1173. 
[197] Hu P, Herrmann R, Bednar A, Saloupis P, Dwyer MA, Yang $P$. Aryl hydrocarbon receptor deficiency causes dysregulated cellular matrix metabolism and age-related macular degeneration-like pathology. Proc Natl Acad Sci U S A (2013) 110: E4069-78.

[198] Golbidi S, Badran M, Laher I. Diabetes, and alpha lipoic Acid. Front Pharmacol (2011) 2: 69. doi: 10.3389/fphar.2011.00069. PMID: 22125537.

[199] Bouzid MA, Filaire E, McCall A, Fabre C. Radical Oxygen Species, Exercise and Aging: An Update. Sports Med (2015) $45,1245-1261$.

[200] Zhang WJ, Frei B. $\alpha$-Lipoic acid inhibits TNF-a-induced NF- $\kappa \mathrm{B}$ activation and adhesion molecule expression in human aortic endothelial cells FASEB J (2001) 15 (13): 2423-2432.

[201] Lingappan K. NF- $\kappa B$ in oxidative stress. Current Opinion Toxicology (2018) 7: 81-86.

[202] Tak PP, Firestein GS. NF-кB: a key role in inflammatory diseases. J Clin Invest (2001) 107: 7-11.

[203] Oh BK, Ho JM, Shi WS, Young YR, Byung SK, Oh HLKS. Euonymus alatus extract attenuates LPS-induced NF- $\mathrm{B}$ activation via IKK $\beta$ inhibition in RAW 264.7 cells. J Ethnopharmacol (2011) 134: 288-293.

[204] Baldwin AS. The transcription factor NF-kB and human disease. J Clin. Invest (2001) 107: 3-6. 